\title{
Accumulation and Distribution of Fertilizer Nitrogen and Nodule-Fixed Nitrogen in Soybeans with Dual Root Systems
}

\author{
Rui Zhang ${ }^{1}$, Cong Wang ${ }^{1}$, Wenzhi Teng ${ }^{1}$, Jing Wang ${ }^{1}$, Xiaochen Lyu ${ }^{1}$, Shoukun Dong ${ }^{1}$ \\ Shuang Kang ${ }^{2}$, Zhenping Gong ${ }^{1, *}$ and Chunmei Ma ${ }^{1, *}$ \\ 1 College of Agriculture, Northeast Agricultural University, Harbin 150030, China; \\ zhang134rui@163.com (R.Z.); w15774517432@163.com (C.W.); twz1024@163.com (W.T); \\ crysta1900313@163.com (J.W.); xiaochenlyu@163.com (X.L.); shoukundong@163.com (S.D.) \\ 2 Heilongjiang Academy of Land Reclamation Sciences, Harbin 150038, China; ks92511@163.com \\ * Correspondence: gzpyx2004@163.com (Z.G.); chunmm518@163.com (C.M.)
}

Received: 28 February 2020; Accepted: 10 March 2020; Published: 14 March 2020

\begin{abstract}
The soybean (Glycine max L. Merr.) is a crop with a high demand for nitrogen (N). The root nodules that form in soybeans can fix atmospheric $\mathrm{N}$ effectively, yet the goal of achieving high yields cannot be met by relying solely on nodule-fixed $\mathrm{N}$. Nonetheless, the application of $\mathrm{N}$ fertilizer may inhibit nodule formation and biological $\mathrm{N}$ fixation (BNF), but the underpinning mechanisms are still unclear. In this study, we grafted the roots of non-nodulated soybeans onto nodulated soybeans to generate plants with dual root system. The experiment included three treatments conducted under sand culture conditions with $\mathrm{NO}_{3}^{-}$and $\mathrm{NH}_{4}^{+}$as $\mathrm{N}$ sources. Treatment I: The non-nodulated roots on one side received $50 \mathrm{mg} \cdot \mathrm{L}^{-1}{ }^{15} \mathrm{NO}_{3}^{-}$or ${ }^{15} \mathrm{NH}_{4}{ }^{+}$, and the nodulated roots on the other side were not treated. Treatment II: The non-nodulated roots received $50 \mathrm{mg} \cdot \mathrm{L}^{-1}{ }^{15} \mathrm{NO}_{3}^{-}$or ${ }^{15} \mathrm{NH}_{4}^{+}$, and the nodulated roots received $50 \mathrm{mg} \cdot \mathrm{L}^{-1}{ }^{14} \mathrm{NO}_{3}^{-}$or ${ }^{14} \mathrm{NH}_{4}^{+}$. Treatment III: Both non-nodulated and nodulated roots received $50 \mathrm{mg} \cdot \mathrm{L}^{-1}{ }^{15} \mathrm{NO}_{3}^{-}$or ${ }^{15} \mathrm{NH}_{4}^{+}$. The results showed the following: (1) Up to $81.5 \%-87.1 \%$ of the $\mathrm{N}$ absorbed by the soybean roots and fixed by the root nodules was allocated to shoot growth, leaving $12.9 \%-18.5 \%$ for root and nodule growth. Soybeans preferentially used fertilizer $\mathrm{N}$ in the presence of a $\mathrm{NO}_{3}^{-}$or $\mathrm{NH}_{4}^{+}$supply. After the absorbed fertilizer $\mathrm{N}$ and nodule-fixed $\mathrm{N}$ was transported to the shoots, a portion of it was redistributed to the roots and nodules. The $\mathrm{N}$ required for root growth was primarily derived from the $\mathrm{NO}_{3}^{-}$or $\mathrm{NH}_{4}^{+}$assimilated by the roots and the $\mathrm{N}$ fixed by the nodules, with a small portion translocated from the shoots. The $\mathrm{N}$ required for nodule growth was primarily contributed by nodule-fixed $\mathrm{N}$ with a small portion translocated from the shoots, whereas the $\mathrm{NO}_{3}^{-}$or $\mathrm{NH}_{4}^{+}$that was assimilated by the roots was not directly supplied to the nodules. (2) Based on observations of the shoots and one side of the roots and nodules in the dual root system as an $\mathrm{N}$ translocation system, we proposed a method for calculating the $\mathrm{N}$ translocation from soybean shoots to roots and nodules during the $R_{1}-R_{5}$ stages based on the difference in the ${ }^{15} \mathrm{~N}$ abundance. Our calculations showed that when adding $\mathrm{N}$ at a concentration of $50 \mathrm{mg} \cdot \mathrm{L}^{-1}$, the $\mathrm{N}$ translocated from the shoots during the $\mathrm{R}_{1}-\mathrm{R}_{5}$ stages accounts for $29.6 \%-52.3 \%$ of the $\mathrm{N}$ accumulation in nodulated roots $\left(\right.$ Root $_{n}$ ) and $9.4 \%-16.6 \%$ of the $\mathrm{N}$ accumulation in Nodule ${ }_{n}$ of soybeans. Through the study of this experiment, the absorption, distribution and redistribution characteristics of fertilizer $\mathrm{N}$ and root nodule $\mathrm{N}$ fixation in soybean can be clarified, providing a theoretical reference for analyzing the mechanisms of the interaction between fertilizer $\mathrm{N}$ and nodule-fixed $\mathrm{N}$.
\end{abstract}

Keywords: soybean dual root system; $\mathrm{N}$ accumulation; distribution; remobilization; $\mathrm{NO}_{3}^{-} ; \mathrm{NH}_{4}^{+}$ 


\section{Introduction}

Leguminous crops and rhizobia form nodules in soybean roots through complex interactions to efficiently fix atmospheric $\mathrm{N}$ for the $\mathrm{N}$ nutrient supply. However, achieving the goal of high yields in leguminous crops is not possible by relying solely on nodule-fixed $\mathrm{N}$. The application of $\mathrm{N}$ fertilizer can considerably increase the yields of leguminous crops [1-4]. In peanut growing fields, the application of urea- $\mathrm{N}$ is a better way to increase the supply of $\mathrm{N}$ from root nodules and improves the $\mathrm{N}$ use efficiency [5]. Nonetheless, $\mathrm{N}$ application may inhibit nodule formation and $\mathrm{N}$ fixation [6-15]. Many researchers have reported that the application of $\mathrm{NO}_{3}-\mathrm{N}$ reduces the weight of the root nodules because high levels of $\mathrm{NO}_{3}-\mathrm{N}$ lead to a sharp decrease in the proportion of photosynthetic products transported to the root nodules and a corresponding increase to the stem and root [16-19]. In addition, Minchin et al. [18] and Carroll et al. [20] indicated that $\mathrm{NO}_{3}^{-}$inhibits the nitrogenase activity in root nodules by increasing their $\mathrm{O}_{2}$ diffusion barrier. Moreover, Munns [21] and Wahab et al. [22] considered that $\mathrm{NO}_{3}^{-}$affects the number of root nodules by inhibiting root hair formation and rhizobial infections in leguminous crops. Gan et al. [23] found that applying a higher concentration of $\mathrm{N}$ fertilizer markedly reduced the nodule number and nodule-fixed $\mathrm{N}$ in soybeans, whereas a lower concentration of $\mathrm{N}$ fertilizer did the opposite.

Many experiments have used the split-root system [24]. Xia et al. [25] conducted a study using dual root system, in which a high concentration of $\mathrm{N}$ was added to one side of the roots and no $\mathrm{N}$ was added to the other side. They found that the number of root nodules decreased in the side receiving a high concentration of $\mathrm{N}$, whereas the number increased in the side without added $\mathrm{N}$. This finding shows that high $\mathrm{N}$ concentrations have a local contact effect in inhibiting the formation and growth of root nodules. Fujikake et al. [26] reported that following the addition of $\mathrm{NO}_{3}^{-}$to soybeans, the diameter growth of the root nodules completely stopped; however, after $\mathrm{NO}_{3}^{-}$withdrawal from the nutrient solution, the growth of the root nodules rapidly recovered to the original normal rate. This observation suggests that the $\mathrm{NO}_{3}^{-}$-induced inhibition of root nodule growth is a reversible process. Using a split-root system, Kosslak et al. [27] inoculated rhizobia into one side of soybean roots, and 10 days later, they inoculated the other side of the roots. They showed that earlier rhizobia inoculation on one side of the roots inhibited nodulation on the other side. Using peas, van Brussel et al. [28] came to a similar conclusion in that the presence of nodules on one side of the roots inhibits nodule formation on the other side, which shows autoregulation.

The $\mathrm{N}$ utilization rate of plants determined by the ${ }^{15} \mathrm{~N}$ isotope tracer method can truly reflect the status of fertilizer utilization by plants. Oghoghorie and Pate [29] divided the pea roots into the upper and lower parts and separated the roots into different treatments, with ${ }^{15} \mathrm{~N}$-labeled $\mathrm{N}_{2}$ being added to the upper roots in one treatment and ${ }^{15} \mathrm{~N}$-labeled $\mathrm{NO}_{3}^{-}$being added to the upper roots in the other treatment. Following treatment, ${ }^{15} \mathrm{~N}$ was detected not only in the shoots but also in the lower roots and nodules. Silva et al. [30] applied ${ }^{15} \mathrm{~N}$ urea to soybean leaves and stems, and found that in 71 days after marking, the content of ${ }^{15} \mathrm{~N}$ aboveground decreased with time, whereas it increased in the roots. Moreover, Oghoghorie and Pate [29] added ${ }^{15} \mathrm{~N}$-labeled $\mathrm{NO}_{3}^{-}$onto the $3 \mathrm{rd}, 7 \mathrm{th}$, and 12 th leaves and detected ${ }^{15} \mathrm{~N}$ in both the aboveground and belowground parts of the peas. Akria et al. [9] used the soybean double root system to supply ${ }^{15} \mathrm{NO}_{3}^{-}$at different concentrations on one side and no $\mathrm{N}$ on the other side. This study found that ${ }^{15} \mathrm{~N}$ markers were also detected in the roots and root nodules on the supplied side and increased with the increase in $\mathrm{N}$ concentration. Reynnolds et al. [31] used the soybean root-dividing system, where ${ }^{13} \mathrm{NH}_{4}^{+}$was applied on one side and no $\mathrm{N}$ was supplied on the other side, and detected an abundance of ${ }^{13} \mathrm{~N}$ amino acids in the $\mathrm{N}$-supplied side of the root, and ${ }^{13} \mathrm{~N}$ markers were detected on both the nodes and the supplied side, indicating that $\mathrm{N}$ in the leaf stem was also transported to the root and root nodules. 
Previous studies have shown that the $\mathrm{N}$ absorbed externally by legumes is transferred to other organs in the plant, but most studies do not show the ratio of $\mathrm{N}$ accumulation and distribution in the plant. In this study, ${ }^{15} \mathrm{~N}$-labeled $\mathrm{NO}_{3}^{-}$and $\mathrm{NH}_{4}^{+}$were added to the root system planted under sand culture conditions. The $\mathrm{N}$ accumulation and ${ }^{15} \mathrm{~N}$ abundance in soybean plants at the $\mathrm{R}_{1}$ and $\mathrm{R}_{5}$ stages were measured and analyzed to understand how $\mathrm{N}$ is absorbed, distributed, and remobilized in soybeans. The results provide reference data to understand the characteristics of $\mathrm{N}$ translocation and unravel the systematic regulation of nodule formation in soybeans.

\section{Materials and Methods}

This study was conducted at an experimental area on the campus of Northeast Agricultural University in 2018 and 2019. The experimental area ( $N: 45^{\circ} 74^{\prime}$ and E: $126^{\circ} 73^{\prime}$ ) is located in the Xiangfang District of Harbin, Heilongjiang Province, China. The annual precipitation is $500-550 \mathrm{~mm}$, and the $\geq 10^{\circ} \mathrm{C}$ accumulated temperature is $2700^{\circ} \mathrm{C}$.

\subsection{Experimental Design and Treatments}

\subsubsection{Preparation of Plant Materials with a Dual Root System}

The soybean plants with dual root system was prepared based on the method in Xia et al. [25]. The treatments were conducted using plastic pots with a diameter of $0.3 \mathrm{~m}$ and a height $0.3 \mathrm{~m}$. Each pot was divided into two equal, independent spaces by vertically inserting a custom-made polycarbonate plate that was fitted for the inner shape of the pot and sealed with glue in the middle of the pot. The top of the partition plate was $2 \mathrm{~cm}$ below the rim of the pot. For each partitioned space, a drainage hole with a $1 \mathrm{~cm}$ diameter was drilled in the bottom of each pot. The hole was capped with a piece of gauze to prevent clogging by river sand. Each pot was filled with $20 \mathrm{~kg}$ of washed sand for cultivating the soybean plants with dual root.

Seeds of nodulated soybeans (Glycine max L. cv. Kenfeng 16) and non-nodulated soybeans (Glycine max L. cv. WDD01795, L8-4858, provided by the Crop Research Institute, Chinese Academy of Agricultural Sciences) were drilled into a fine sand medium at a depth of $2 \mathrm{~cm}$ and incubated in a growth chamber at $30^{\circ} \mathrm{C}$ for 3 days. When the distance between the growing point of the cotyledon and the tip of the root was 7 to $10 \mathrm{~cm}$, the roots of the soybean seedlings were rinsed with water and then used for grafting. Two seedlings of nodulated and non-nodulated soybeans were chosen and an incision of $0.5-1.0 \mathrm{~cm}$ (without cutting off) was made with a sterilized blade, which extended upward or downward slightly above the middle point of the hypocotyl. The non-nodulated seedling was cut from the cotyledon toward the root (Figure 1A), whereas the nodulated seedling was cut from the root toward the cotyledon (Figure 1B). The two seedlings were cross-inserted into their cuts (Figure 1C) and clipped with a grafting clip. The root system of the two seedlings were planted separately into the fine sand medium on both sides of the partition plate in the pot, with the grafting site exactly on the top of the partition plate. The grafted seedlings were allowed to grow inside a weather-tight enclosure for a week. The grafting clip was then removed and the upper part of each non-nodulated seedling was cut from the grafting site, leaving its combined site and lower parts. This procedure generated seedlings with dual root system (nodulated and non-nodulated) and the shoots of a nodulated cultivar. The plants were grown under farmland conditions and treated experimentally. (Figure 1D) shows the roots of a soybean plant with a dual root system at the time of sampling, with non-nodulated roots $\left(\operatorname{Root}_{\text {non }}\right)$ on the left and nodulated roots $\left(\operatorname{Root}_{n}\right)$ on the right side. 


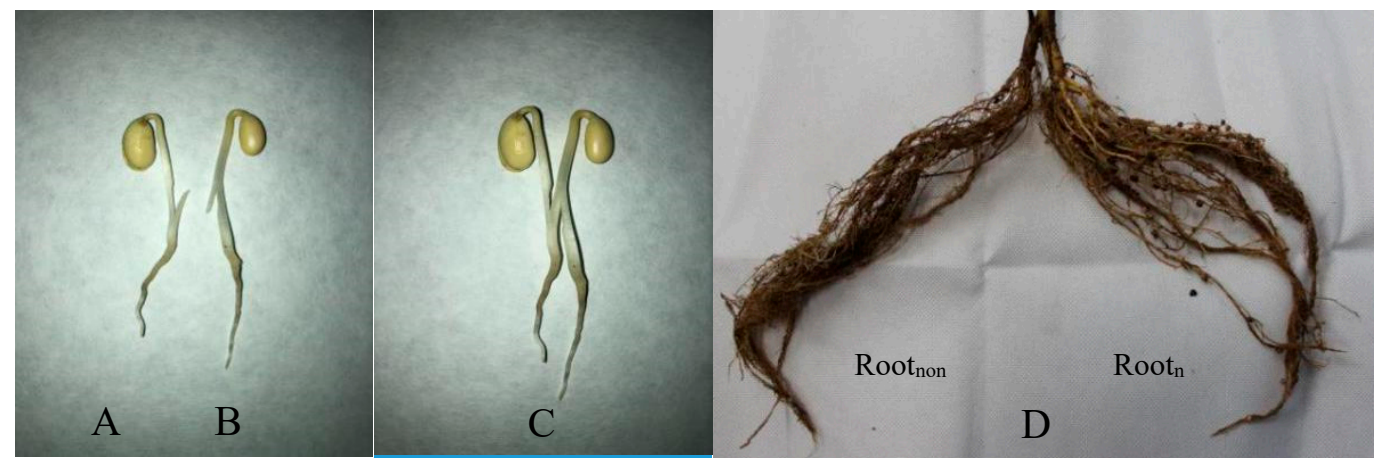

Figure 1. Soybean plant with dual root system. (A) Non-nodulated seedling, (B) nodulated seedling, (C) two seedlings cross-inserted into their cuts and clipped with a grafting clip, and (D) roots of a soybean plant with a dual root system at the time of sampling, with non-nodulated roots (Root non $_{\text {) }}$ on the left and nodulated roots $\left(\operatorname{Root}_{\mathrm{n}}\right)$ on the right side.

\subsubsection{Experimental Treatments}

Three treatments were conducted with $\mathrm{NO}_{3}^{-}$and $\mathrm{NH}_{4}^{+}$as $\mathrm{N}$ sources $\left(50 \mathrm{mg} \cdot \mathrm{L}^{-1}\right.$ each). In Treatment I, a nutrient solution containing ${ }^{15} \mathrm{~N}$-labeled $\mathrm{NO}_{3}^{-}$or $\mathrm{NH}_{4}^{+}$was added to Root $_{\text {non, }}$, whereas an $\mathrm{N}$-free nutrient solution was added to $\operatorname{Root}_{\mathrm{n}}$. In Treatment II, a nutrient solution containing ${ }^{15} \mathrm{~N}$-labeled $\mathrm{NO}_{3}^{-}$

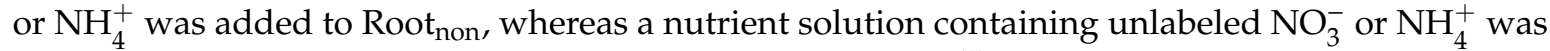
added to Root $_{\mathrm{n}}$. In Treatment III, a nutrient solution containing ${ }^{15} \mathrm{~N}$-labeled $\mathrm{NO}_{3}^{-}$or $\mathrm{NH}_{4}^{+}$was added to both Root $_{\text {non }}$ and Root $_{\mathrm{n}}$. Three treatments are detailed in Table 1 . The $\mathrm{N}$ free nutrient solution contained the following: $136 \mathrm{mg} \cdot \mathrm{L}^{-1} \mathrm{KH}_{2} \mathrm{PO}_{4}, 240 \mathrm{mg} \cdot \mathrm{L}^{-1} \mathrm{MgSO}_{4}, 220 \mathrm{mg} \cdot \mathrm{L}^{-1} \mathrm{CaCl}_{2}, 4.9 \mathrm{mg} \cdot \mathrm{L}^{-1} \mathrm{MnCl}_{2} \cdot 4 \mathrm{H}_{2} \mathrm{O}$, $2.86 \mathrm{mg} \cdot \mathrm{L}^{-1} \mathrm{H}_{3} \mathrm{BO}_{3}, 0.22 \mathrm{mg} \cdot \mathrm{L}^{-1} \mathrm{ZnSO}_{4} \cdot 7 \mathrm{H}_{2} \mathrm{O}, 0.08 \mathrm{mg} \cdot \mathrm{L}^{-1} \mathrm{CuSO}_{4} \cdot 5 \mathrm{H}_{2} \mathrm{O}, 0.03 \mathrm{mg} \cdot \mathrm{L}^{-1} \mathrm{Na}_{2} \mathrm{MoO}_{4} \cdot \mathrm{H}_{2} \mathrm{O}$, $5.57 \mathrm{mg} \cdot \mathrm{L}^{-1} \mathrm{FeSO}_{4} \cdot 7 \mathrm{H}_{2} \mathrm{O}$, and $7.45 \mathrm{mg} \cdot \mathrm{L}^{-1} \mathrm{Na}_{2}$ EDTA. The $\mathrm{NO}_{3}^{-}$-containing nutrient solution was prepared by adding $360.7 \mathrm{mg} \cdot \mathrm{L}^{-1} \mathrm{KNO}_{3}$ to the $\mathrm{N}$-free nutrient solution, and the $\mathrm{NH}_{4}^{+}$-containing nutrient solution was formulated by adding $235.7 \mathrm{mg} \cdot \mathrm{L}^{-1}\left(\mathrm{NH}_{4}\right)_{2} \mathrm{SO}_{4}$ to the $\mathrm{N}$-free nutrient solution. The ${ }^{15} \mathrm{~N}$ abundance of both ${ }^{15} \mathrm{~N}$-labeled $\mathrm{NO}_{3}^{-}$and $\mathrm{NH}_{4}^{+}$was $3.63 \%$.

Table 1. Experimental treatments.

\begin{tabular}{ccclc}
\hline & \multicolumn{2}{c}{$\mathrm{NO}_{3}^{-}$} & \multicolumn{2}{c}{$\mathrm{NH}_{4}^{+}$} \\
\cline { 2 - 5 } & Root $_{\text {non }}$ & Root $_{\mathbf{n}}$ & Root $_{\text {non }}$ & Root \\
\hline I & ${ }^{15} \mathrm{NO}_{3}{ }^{-}$ & $\mathrm{N}_{\text {free }}$ & ${ }^{15} \mathrm{NH}_{4}^{+}$ & $\mathrm{N}$ free \\
II & ${ }^{15} \mathrm{NO}_{3}{ }^{-}$ & ${ }^{14} \mathrm{NO}_{3}{ }^{-}$ & ${ }^{15} \mathrm{NH}_{4}^{+}$ & ${ }^{14} \mathrm{NH}_{4}{ }^{+}$ \\
III & ${ }^{15} \mathrm{NO}_{3}^{-}$ & ${ }^{15} \mathrm{NO}_{3}^{-}$ & ${ }^{15} \mathrm{NH}_{4}^{+}$ & ${ }^{15} \mathrm{NH}_{4}^{+}$ \\
\hline
\end{tabular}

Before the full expansion of the opposite true leaves, the soybean seedlings were irrigated once a day with $250 \mathrm{~mL}$ of distilled water on each side of the root system [25]. Following the full expansion of the opposite true leaves, the seedlings were irrigated once a day with $250 \mathrm{~mL}$ of the corresponding nutrient solution on each side of the root system until the $R_{1}$ stage. From the $R_{1}$ stage on, the seedlings were irrigated twice a day, once in the morning and once in the evening, with $250 \mathrm{~mL}$ of the corresponding nutrient solution for each side of the root system until the end of the experiment. When the opposite true leaves were fully expanded, all the roots were inoculated with rhizobia as follows: Soybean root nodules harvested from the field during the previous year and stored in a freezer were washed, ground, and then added to the nutrient solutions at $5 \mathrm{~g} \cdot \mathrm{L}^{-1}$. This method was used to inoculate soybean with soil rhizobia continuously for 5 days. Previous experiments showed that this method was feasible for soybean inoculation, and there would be spontaneous nodulation of rhizobia in the soil community [25,32]. The main N-fixing rhizobia in soil belonged to Bradyrhizobium, Bradyrhizobium japonicum, and B. liaoningense were the dominant bacteria [33]. 


\subsection{Sampling and Parameter Analysis}

Samples were taken at the $\mathrm{R}_{1}$ and $\mathrm{R}_{5}$ stages [34]. The plants were separated into different parts, deactivated at $105{ }^{\circ} \mathrm{C}$ for $30 \mathrm{~min}$, and then dried at $85^{\circ} \mathrm{C}$. Dry samples were used to analyze the ${ }^{15} \mathrm{~N}$ abundance, dry weight, and $\mathrm{N}$ content of each part.

Plant $\mathrm{N}$ content analysis: The plant $\mathrm{N}$ content was determined using a B324 automatic Kjeldahl analyzer after digestion with concentrated $\mathrm{H}_{2} \mathrm{SO}_{4}\left(\mathrm{~K}_{2} \mathrm{SO}_{4}\right.$ and $\mathrm{CuSO}_{4}$ as catalysts).

${ }^{15} \mathrm{~N}$ abundance analysis: After plant $\mathrm{N}$ content analysis by the Kjeldahl method, the titrated samples were concentrated and allowed to react with lithium hypobromite to produce $\mathrm{N}_{2}$ under freezing-vacuum conditions. The ${ }^{15} \mathrm{~N}$ abundance was determined using a mass spectrometer (Thermo-Fisher Delta $\mathrm{V}$ Advantage IRMS) equipped with a dual-inlet system.

\subsection{Data Calculations}

The percent of ${ }^{15} \mathrm{~N}$-labeled $\mathrm{N}$ derived from fertilizer $\left({ }^{15} \mathrm{Ndff} \%\right)$ in plants was calculated as:

$$
{ }^{15} \mathrm{Ndff} \%=\frac{\mathrm{f}_{\text {treatment }}-\mathrm{f}_{\text {nature }}}{\mathrm{f}_{\text {fertilizer }}-\mathrm{f}_{\text {nature }}} \times 100 \%
$$

where $\mathrm{f}_{\text {nature }}$ is the natural ${ }^{15} \mathrm{~N}$ abundance, $\mathrm{f}_{\text {fertilizer }}$ is the ${ }^{15} \mathrm{~N}$ abundance of the fertilizer, and $\mathrm{f}_{\text {treatment }}$ is the ${ }^{15} \mathrm{~N}$ abundance of the treatment.

The percent of $\mathrm{N}$ derived from atmosphere $(\mathrm{Ndfa} \%)$ in plants was calculated as:

$$
\mathrm{Ndfa} \%=1-15 \mathrm{Ndff} \%
$$

The percent of ${ }^{14} \mathrm{Nitrogen}$ derived from fertilizer $\left({ }^{14} \mathrm{Ndff} \%\right)$ plus the percent of $\mathrm{N}$ derived from atmosphere (Ndfa\%) was calculated as:

$$
{ }^{14} \mathrm{Ndff} \%+\mathrm{Ndfa} \%=1-{ }^{15} \mathrm{Ndff} \%
$$

Based on the ${ }^{15} \mathrm{~N}$ abundance of each organ, the ratio of $\mathrm{N}$ sources from ${ }^{15} \mathrm{~N},{ }^{14} \mathrm{~N}$, and $\mathrm{N}$-fixing root nodules in each organ can be calculated; if these values are then multiplied by the $\mathrm{N}$ accumulation, the $\mathrm{N}$ accumulation from ${ }^{15} \mathrm{~N},{ }^{14} \mathrm{~N}$, and root nodules in each organ can be obtained.

\subsection{Statistical Analyses}

Descriptive statistics, one-way ANOVA, and correlation tests were performed on the data by IBM SPSS Software version 17.0. The results were mean \pm standard deviation (SD) of three replicates. Duncan test was used for comparison between treatments $(\alpha=0.05)$. All data were tested for normality and homogeneity of variance.

\section{Results}

\subsection{Ratio of Fertilizer $N$ and Root Nodule N Fixation in Soybean Plants}

\subsection{1. ${ }^{15} \mathrm{~N}$ Abundance (\%) Difference in Soybean Plants with Dual Root}

Table 2 shows the ${ }^{15} \mathrm{~N}$ abundance in the various parts of soybean plants with dual root system for Treatments I, II, and III. The ${ }^{15} \mathrm{~N}$ abundance in the vegetative organs of soybean plants differed significantly among the three treatments, indicating that the different treatments resulted in considerable differences in the ${ }^{15} \mathrm{~N}$ abundance in various organs. 
Table 2. ${ }^{15} \mathrm{~N}$ abundance (\%) in plant organs of soybean with dual root

\begin{tabular}{cccccccc}
\hline \multirow{2}{*}{ Stages } & \multirow{2}{*}{ Organs } & \multicolumn{5}{c}{ NO $_{3}^{-}$} & \multicolumn{3}{c}{ NH $_{4}^{+}$} \\
\cline { 3 - 8 } & & $\mathbf{I}$ & II & III & I & II & III \\
\hline \multirow{4}{*}{$\mathbf{R}_{\mathbf{1}}$} & Root $_{\text {non }}$ & $2.73 \pm 0.11 \mathrm{ab}$ & $2.58 \pm 0.06 \mathrm{~b}$ & $2.91 \pm 0.04 \mathrm{a}$ & $2.79 \pm 0.05 \mathrm{~b}$ & $2.59 \pm 0.06 \mathrm{c}$ & $2.99 \pm 0.02 \mathrm{a}$ \\
& Root $_{\mathbf{n}}$ & $0.96 \pm 0.01 \mathrm{~b}$ & $0.77 \pm 0.04 \mathrm{c}$ & $2.45 \pm 0.02 \mathrm{a}$ & $1.01 \pm 0.01 \mathrm{~b}$ & $0.71 \pm 0.02 \mathrm{c}$ & $2.70 \pm 0.03 \mathrm{a}$ \\
& Nodule $_{\mathbf{n}}$ & $0.63 \pm 0.02 \mathrm{~b}$ & $0.58 \pm 0.03 \mathrm{~b}$ & $0.88 \pm 0.01 \mathrm{a}$ & $0.62 \pm 0.01 \mathrm{~b}$ & $0.56 \pm 0.01 \mathrm{c}$ & $0.96 \pm 0.01 \mathrm{a}$ \\
& Shoot & $1.45 \pm 0.04 \mathrm{~b}$ & $1.34 \pm 0.06 \mathrm{~b}$ & $2.16 \pm 0.03 \mathrm{a}$ & $1.51 \pm 0.02 \mathrm{~b}$ & $1.34 \pm 0.01 \mathrm{c}$ & $2.38 \pm 0.02 \mathrm{a}$ \\
\hline \multirow{4}{*}{$\mathbf{R}_{\mathbf{5}}$} & Root $_{\text {non }}$ & $2.46 \pm 0.09 \mathrm{~b}$ & $2.27 \pm 0.08 \mathrm{~b}$ & $2.74 \pm 0.01 \mathrm{a}$ & $2.55 \pm 0.17 \mathrm{a}$ & $2.47 \pm 0.11 \mathrm{a}$ & $2.76 \pm 0.09 \mathrm{a}$ \\
& Root $_{\mathbf{n}}$ & $0.73 \pm 0.02 \mathrm{~b}$ & $0.76 \pm 0.03 \mathrm{~b}$ & $1.87 \pm 0.08 \mathrm{a}$ & $0.80 \pm 0.04 \mathrm{~b}$ & $0.70 \pm 0.03 \mathrm{~b}$ & $1.98 \pm 0.05 \mathrm{a}$ \\
& Nodule $_{\mathbf{n}}$ & $0.51 \pm 0.00 \mathrm{~b}$ & $0.52 \pm 0.02 \mathrm{~b}$ & $0.76 \pm 0.00 \mathrm{a}$ & $0.52 \pm 0.01 \mathrm{~b}$ & $0.51 \pm 0.01 \mathrm{~b}$ & $0.75 \pm 0.01 \mathrm{a}$ \\
& Shoot & $0.94 \pm 0.01 \mathrm{~b}$ & $0.94 \pm 0.03 \mathrm{~b}$ & $1.44 \pm 0.03 \mathrm{a}$ & $0.94 \pm 0.02 \mathrm{~b}$ & $1.01 \pm 0.02 \mathrm{~b}$ & $1.61 \pm 0.04 \mathrm{a}$ \\
\hline
\end{tabular}

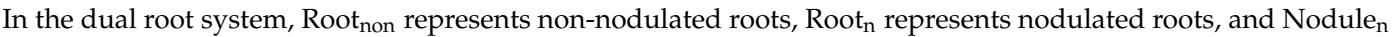
represents nodules on the same side of nodulated roots. The values are the means \pm standard error $(n=3)$. Different lowercase letters indicate significant differences between treatments at the $5 \%$ level. Treatments I, II, and III are compared horizontally.

In Treatment I, under $\mathrm{NO}_{3}^{-}$and $\mathrm{NH}_{4}^{+} \mathrm{N}$ sources, the ${ }^{15} \mathrm{~N}$ abundance in Root $_{\text {non }}$ at the $\mathrm{R}_{1}$ and $R_{5}$ stages was lower than that of the $\mathrm{N}$ fertilizer $(3.63 \%)$. However, the ${ }^{15} \mathrm{~N}$ abundance in Root $_{n}$ and Nodule $_{n}$ at the $R_{1}$ and $R_{5}$ stages remained higher than the natural ${ }^{15} \mathrm{~N}$ abundance $(0.365 \%)$. The ${ }^{15} \mathrm{~N}$ abundance in the soybean Shoot at the $\mathrm{R}_{1}$ stage was higher than the natural ${ }^{15} \mathrm{~N}$ abundance $(0.365 \%)$ and lower than the ${ }^{15} \mathrm{~N}$ abundance of fertilizer $\mathrm{N}$ (3.63\%). In Treatments II and III, under $\mathrm{NO}_{3}^{-}$and $\mathrm{NH}_{4}^{+} \mathrm{N}$ sources, the ${ }^{15} \mathrm{~N}$ abundance at the $\mathrm{R}_{1}$ and $\mathrm{R}_{5}$ stages in Root ${ }_{\text {non }}$ was lower than that of fertilizer $\mathrm{N}(3.63 \%)$ and higher than the natural ${ }^{15} \mathrm{~N}$ abundance $(0.365 \%)$. There were no significant differences in the ${ }^{15} \mathrm{~N}$ abundance between the $\mathrm{NO}_{3}^{-}$and $\mathrm{NH}_{4}^{+} \mathrm{N}$ sources for Treatments I, II, and III. However, during three treatments, the ${ }^{15} \mathrm{~N}$ abundance in all the soybean organs under different treatments at $\mathrm{R}_{5}$ was lower than it was at the $\mathrm{R}_{1}$ stage.

\subsubsection{Ratio of N Absorbed from Different Sources in Dual Root Soybeans}

Table 3 shows that for Treatment I under $\mathrm{NO}_{3}^{-}$and $\mathrm{NH}_{4}^{+}$sources at the $\mathrm{R}_{1}$ and $\mathrm{R}_{5}$ stages, most of the $\mathrm{N}$ in Root $_{\text {non }}$ came from the fertilizer $\mathrm{N}$ that was self-absorbed by the roots. However, these results illustrate that at the $R_{1}$ and $R_{5}$ stages, most of the $N$ in Root $_{n}$ and Nodule $e_{n}$ came from the nodule-fixed $\mathrm{N}$ in this root system. At the $\mathrm{R}_{1}$ and $\mathrm{R}_{5}$ stages, nodule-fixed $\mathrm{N}$ contributed a larger proportion to the supply for the Shoot. 
Table 3. Ratio of $\mathrm{N}$ absorbed from different sources in dual root soybeans (\%).

\begin{tabular}{|c|c|c|c|c|c|c|}
\hline & \multirow{2}{*}{ Stages } & \multirow{2}{*}{ Organs } & \multicolumn{2}{|c|}{$\mathrm{NO}_{3}^{-}$} & \multicolumn{2}{|c|}{$\mathrm{NH}_{4}^{+}$} \\
\hline & & & ${ }^{15} \mathrm{Ndff} \%$ & Ndfa\% $\%$ & ${ }^{15} \mathrm{Ndff} \%$ & Ndfa\% \\
\hline \multirow{9}{*}{ I } & \multirow{4}{*}{$\mathbf{R}_{1}$} & Root $_{\text {non }}$ & $72.4 \pm 3.46 a$ & $27.6 \pm 3.46 b$ & $74.2 \pm 1.58 \mathrm{a}$ & $25.8 \pm 1.58 b$ \\
\hline & & $\operatorname{Root}_{n}$ & $18.3 \pm 0.34 b$ & $81.7 \pm 0.34 a$ & $19.7 \pm 0.34 b$ & $80.3 \pm 0.34 a$ \\
\hline & & Nodule $_{n}$ & $8.0 \pm 0.51 b$ & $92.0 \pm 0.51 a$ & $7.9 \pm 0.33 b$ & $92.1 \pm 0.33 a$ \\
\hline & & Shoot & $33.1 \pm 0.27 b$ & $66.9 \pm 0.27 a$ & $34.9 \pm 0.60 b$ & $65.1 \pm 0.6 a$ \\
\hline & \multirow{5}{*}{$\mathbf{R}_{5}$} & $\operatorname{Root}_{\text {non }}$ & $64.1 \pm 2.74 a$ & $35.9 \pm 2.74 b$ & $67.0 \pm 5.21 a$ & $33.0 \pm 5.21 b$ \\
\hline & & $\operatorname{Root}_{n}$ & $11.2 \pm 0.54 b$ & $88.8 \pm 0.54 a$ & $13.3 \pm 1.15 b$ & $86.7 \pm 1.15 a$ \\
\hline & & Nodule $_{n}$ & $4.3 \pm 0.10 b$ & $95.7 \pm 0.10 a$ & $4.8 \pm 0.18 b$ & $95.2 \pm 0.18 a$ \\
\hline & & Shoot & $17.6 \pm 0.27 b$ & $82.4 \pm 0.26 a$ & $17.6 \pm 0.28 b$ & $82.4 \pm 0.28 a$ \\
\hline & & & ${ }^{15} \mathrm{Ndff} \%$ & ${ }^{14} \mathrm{Ndff} \%+\mathrm{Ndfa} \%$ & ${ }^{15} \mathrm{Ndff} \%$ & ${ }^{14} \mathrm{Ndff} \%+\mathrm{Ndfa} \%$ \\
\hline \multirow{9}{*}{ II } & \multirow{4}{*}{$\mathbf{R}_{1}$} & Root $_{\text {non }}$ & $68.0 \pm 1.92 a$ & $32.0 \pm 1.92 b$ & $68.1 \pm 1.81 \mathrm{a}$ & $31.9 \pm 1.81 b$ \\
\hline & & $\operatorname{Root}_{n}$ & $12.4 \pm 1.24 b$ & $87.6 \pm 1.24 a$ & $10.7 \pm 0.63 b$ & $89.3 \pm 0.63 a$ \\
\hline & & Nodule $_{n}$ & $6.6 \pm 0.80 b$ & $93.4 \pm 0.80 a$ & $6.0 \pm 0.30 b$ & $94.0 \pm 0.30 \mathrm{a}$ \\
\hline & & Shoot & $30.0 \pm 0.49 b$ & $70.0 \pm 0.49 a$ & $30.0 \pm 0.35 b$ & $70.0 \pm 0.35 a$ \\
\hline & \multirow{4}{*}{$\mathbf{R}_{5}$} & Root $_{\text {non }}$ & $58.5 \pm 2.58 a$ & $41.5 \pm 2.58 b$ & $64.6 \pm 3.42 a$ & $35.4 \pm 3.42 b$ \\
\hline & & $\operatorname{Root}_{n}$ & $12.2 \pm 0.88 b$ & $87.8 \pm 0.88 a$ & $10.2 \pm 0.95 b$ & $89.8 \pm 0.95 a$ \\
\hline & & Nodule $_{n}$ & $4.7 \pm 0.42 b$ & $95.3 \pm 0.42 a$ & $4.6 \pm 0.28 b$ & $95.4 \pm 0.28 a$ \\
\hline & & Shoot & $17.6 \pm 0.66 b$ & $82.4 \pm 0.66 a$ & $19.8 \pm 0.37 b$ & $80.2 \pm 0.37 a$ \\
\hline & & & ${ }^{15} \mathrm{Ndff} \%$ & Ndfa $\%$ & ${ }^{15} \mathrm{Ndff} \%$ & $\mathrm{Ndfa} \%$ \\
\hline \multirow{8}{*}{ III } & \multirow{4}{*}{$\mathbf{R}_{\mathbf{1}}$} & Root $_{\text {non }}$ & $78.0 \pm 1.15 a$ & $22.0 \pm 1.15 b$ & $80.5 \pm 0.68 a$ & $19.5 \pm 0.68 b$ \\
\hline & & $\operatorname{Root}_{n}$ & $63.7 \pm 0.66 a$ & $36.3 \pm 0.66 b$ & $71.4 \pm 0.96 a$ & $28.6 \pm 0.96 b$ \\
\hline & & Nodule $_{n}$ & $15.8 \pm 0.25 b$ & $84.2 \pm 0.25 a$ & $18.3 \pm 0.30 b$ & $81.7 \pm 0.30 \mathrm{a}$ \\
\hline & & Shoot & $55.0 \pm 1.23 a$ & $45.0 \pm 1.23 b$ & $61.6 \pm 1.48 a$ & $38.4 \pm 1.48 b$ \\
\hline & \multirow{4}{*}{$\mathbf{R}_{5}$} & $\operatorname{Root}_{\text {non }}$ & $72.7 \pm 0.18 a$ & $27.3 \pm 0.18 b$ & $73.4 \pm 2.71 \mathrm{a}$ & $26.6 \pm 2.71 b$ \\
\hline & & $\operatorname{Root}_{n}$ & $46.0 \pm 2.52 a$ & $54.0 \pm 2.52 \mathrm{a}$ & $49.6 \pm 1.41 a$ & $50.4 \pm 1.41 a$ \\
\hline & & Nodule $_{n}$ & $11.9 \pm 0.04 b$ & $88.1 \pm 0.04 a$ & $11.8 \pm 0.31 b$ & $88.2 \pm 0.31 \mathrm{a}$ \\
\hline & & Shoot & $32.9 \pm 0.88 b$ & $67.1 \pm 0.88 a$ & $38.1 \pm 0.78 b$ & $61.9 \pm 0.78 a$ \\
\hline
\end{tabular}

In the dual root system, Root $_{n o n}$ represents non-nodulated roots, Root $_{\mathrm{n}}$ represents nodulated roots, and Nodule $_{n}$ represents nodules on the same side as the nodulated roots. ${ }^{15} \mathrm{Ndff} \%$ represents the proportion of ${ }^{15} \mathrm{~N}$-labeled fertilizer $\mathrm{N}, \mathrm{Ndfa} \%$ represents the proportion of nodule-fixed $\mathrm{N}$, and ${ }^{14} \mathrm{Ndff} \%+\mathrm{Ndfa} \%$ represents the proportion of nodule-fixed $\mathrm{N}$ plus unlabeled fertilizer $\mathrm{N}$. The values are the means \pm standard error $(n=3)$. Different lowercase letters indicate significant differences between treatments at the $5 \%$ level. The two $\mathrm{N}$ sources are compared horizontally.

In Treatment II under $\mathrm{NO}_{3}^{-}$and $\mathrm{NH}_{4}^{+} \mathrm{N}$ sources, the results indicate that when $\mathrm{N}$ was added to

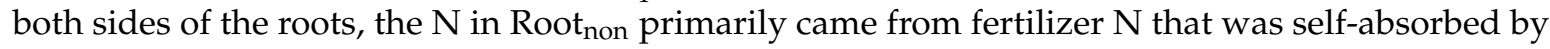
the roots with small proportions from absorbed fertilizer $\mathrm{N}$ and nodule-fixed $\operatorname{Root}_{\mathrm{n}} \mathrm{N}$ (translocated from the Shoot). A comparison with Treatment I revealed that there was little difference in the nutrient proportions of different $\mathrm{N}$ sources in Root $\mathrm{non}_{\text {ns }}$ contributed by the two roots of the dual root system with an addition to both sides versus one side. Furthermore, the proportions of different $\mathrm{N}$ sources in various parts of the soybean plants in Treatments I and II were compared. Similarly, the nutrient proportions contributed by the two roots of the dual root system did not change markedly in the Root ${ }_{n}$, Nodule $_{n}$, or Shoot. These results indicate that the soybean plants contributed similarly to the plant $\mathrm{N}$ with or without $\mathrm{N}$ addition, showing the integrity of fertilizer $\mathrm{N}$ absorption and nodule $\mathrm{N}$ fixation.

No significant differences were detected in the proportions of various $\mathrm{N}$ sources between the $\mathrm{NO}_{3}^{-}$and $\mathrm{NH}_{4}^{+} \mathrm{N}$ sources among Treatments I, II, and III, indicating that the nutritional effect of $\mathrm{NO}_{3}^{-}$ vs. $\mathrm{NH}_{4}^{+}$addition was not markedly different in soybean plants. However, compared with the $\mathrm{R}_{1}$ stage, the $\mathrm{R}_{5}$ stage was associated with a higher proportion of nodule-fixed $\mathrm{N}$ in various organs under different conditions for Treatments I, II, and III, indicating a larger contribution of nodule-fixed $\mathrm{N}$ to soybean plants at the $\mathrm{R}_{5}$ stage than at the $\mathrm{R}_{1}$ stage. 
In both Treatments II and III, the same N concentration was added to both sides of the root system, and the only difference was related to the ${ }^{15} \mathrm{~N}$ abundance. To distinguish among the three $\mathrm{N}$ sources in Treatment II, we calculated the proportion of absorbed ${ }^{14} \mathrm{~N}$-labeled fertilizer $\mathrm{N}$ in various parts of the soybean plants by summing up the proportion of absorbed ${ }^{14} \mathrm{~N}$-labeled fertilizer $\mathrm{N}$ and the proportion of $\mathrm{N}$ from nodule fixation in each part of the soybeans from Treatment II and subtracting the proportion of $\mathrm{N}$ from nodule fixation in the same parts of the soybean plants from Treatment III (Table 4).

Table 4. Proportions of $\mathrm{N}$ from different sources in various organs of soybean plants in Treatment II (\%).

\begin{tabular}{|c|c|c|c|c|c|c|c|}
\hline \multirow{2}{*}{ Stages } & \multirow{2}{*}{ Organs } & \multicolumn{3}{|c|}{$\mathrm{NO}_{3}^{-}$} & \multicolumn{3}{|c|}{$\mathrm{NH}_{4}^{+}$} \\
\hline & & ${ }^{15} \mathrm{Ndff} \%$ & ${ }^{14} \mathrm{Ndff} \%$ & Ndfa $\%$ & ${ }^{15} \mathrm{Ndff} \%$ & ${ }^{14} \mathrm{Ndff} \%$ & Ndfa $\%$ \\
\hline \multirow{4}{*}{$\mathbf{R}_{\mathbf{1}}$} & Root & $68.0 \pm 1.92 \mathrm{a}$ & $10.0 \pm 2.83 c$ & $22.0 \pm 1.15 b$ & $68.1 \pm 1.81 \mathrm{a}$ & $12.4 \pm 1.84 c$ & $19.5 \pm 0.68 b$ \\
\hline & $\operatorname{Root}_{n}$ & $12.4 \pm 1.24 \mathrm{c}$ & $51.3 \pm 0.81 \mathrm{a}$ & $36.3 \pm 0.66 b$ & $10.7 \pm 0.63 c$ & $60.7 \pm 0.54 a$ & $28.6 \pm 0.96 b$ \\
\hline & Nodule $_{n}$ & $6.6 \pm 0.80 c$ & $9.2 \pm 1.00 \mathrm{~b}$ & $84.2 \pm 0.25 a$ & $6.0 \pm 0.30 c$ & $12.3 \pm 0.60 b$ & $81.7 \pm 0.30 \mathrm{a}$ \\
\hline & Shoot & $30.0 \pm 0.49 b$ & $25.0 \pm 1.68 c$ & $45.0 \pm 1.23 a$ & $30.0 \pm 0.35 b$ & $31.6 \pm 1.18 b$ & $38.4 \pm 1.48 \mathrm{a}$ \\
\hline \multirow{4}{*}{$\mathbf{R}_{5}$} & $\operatorname{Root}_{n}$ & $58.5 \pm 2.58 a$ & $14.2 \pm 2.63 c$ & $27.3 \pm 0.18 b$ & $64.6 \pm 3.42 a$ & $8.8 \pm 0.72 c$ & $26.6 \pm 2.71 b$ \\
\hline & $\operatorname{Root}_{n}$ & $12.2 \pm 0.88 c$ & $33.8 \pm 2.63 b$ & $54.0 \pm 2.52 a$ & $10.2 \pm 0.95 c$ & $39.4 \pm 0.52 b$ & $50.4 \pm 1.41 \mathrm{a}$ \\
\hline & Nodule $_{n}$ & $4.7 \pm 0.42 c$ & $7.2 \pm 0.46 b$ & $88.1 \pm 0.04 a$ & $4.6 \pm 0.28 c$ & $7.2 \pm 0.03 b$ & $88.2 \pm 0.31 \mathrm{a}$ \\
\hline & Shoot & $17.6 \pm 0.66 b$ & $15.3 \pm 1.20 b$ & $67.1 \pm 0.88 \mathrm{a}$ & $19.8 \pm 0.37 b$ & $18.3 \pm 0.57 b$ & $61.9 \pm 0.78 \mathrm{a}$ \\
\hline
\end{tabular}

In the dual root system, Root $_{\text {non }}$ represents non-nodulated roots, Root $_{n}$ represents nodulated roots, and Nodule $_{n}$ represents nodules on the same side as the nodulated roots. ${ }^{15} \mathrm{Ndff} \%$ represents the proportion of ${ }^{15} \mathrm{~N}$-labeled fertilizer $\mathrm{N},{ }^{14} \mathrm{Ndff} \%$ represents the proportion of unlabeled fertilizer $\mathrm{N}$, and $\mathrm{Ndfa} \%$ represents the proportion of nodule-fixed $N$. The values are the means \pm standard error $(n=3)$. Different lowercase letters indicate significant differences between treatments at the $5 \%$ level. Three $\mathrm{N}$ sources are compared horizontally.

In Treatment II, there were three $\mathrm{N}$ sources for soybean plants, i.e., absorbed fertilizer $\mathrm{N}$ from Root $_{\text {non, }}$ absorbed fertilizer $\mathrm{N}$ from Root ${ }_{n}$, and nodule-fixed $\mathrm{N}$ from Root $_{\mathrm{n}}$. Under the $\mathrm{NO}_{3}^{-}$and $\mathrm{NH}_{4}^{+}$ $\mathrm{N}$ sources in the $\mathrm{R}_{1}$ stage, Root $_{\text {non }}$ preferentially absorbed the self-assimilated $\mathrm{N}$. At the $\mathrm{R}_{1}$ stage, $51.3 \%$ and $60.7 \%$, respectively, were contributed by absorbed Root $_{n}$ fertilizer N, and $36.3 \%$ and $28.6 \%$, respectively, were contributed by nodule-fixed $\operatorname{Root}_{n} \mathrm{~N}$. At the $\mathrm{R}_{5}$ stage, the corresponding proportions were $33.8 \%$ and $39.4 \%, 54.0 \%$ and $50.4 \%$ for absorbed fertilizer $\mathrm{N}$ from Root $_{\text {non, }}$, absorbed fertilizer $\mathrm{N}$ from Root $_{\mathrm{n}}$, and nodule-fixed $\mathrm{N}$ from Root $_{\mathrm{n}}$, respectively. These results show that when $\mathrm{N}$ was added to both sides of the root system, Root $_{\mathrm{n}}$ also preferentially absorbed the $\mathrm{N}$ that was assimilated by this root system; the proportion of nodule-fixed $\mathrm{N}$ in Root $_{n}$ increased with the increasing $\mathrm{N}$ fixation capacity of the nodules. For the $\mathrm{N}$ in Nodule $_{n}$ at the $\mathrm{R}_{1}$ and $\mathrm{R}_{5}$ stages, nodule-fixed $\mathrm{N}$ was preferentially absorbed by Nodule $n$. Moreover, the proportion of $\mathrm{N}$ in the root nodules contributed by the absorbed fertilizer $\mathrm{N}$ of the two roots of the dual root system was significantly different; that is, the $\mathrm{N}$ from Root $_{\text {non }}$ was less than that from Root $n$. These results show that when $\mathrm{N}$ was added to both sides of the root system, the Shoot primarily absorbed fertilizer $\mathrm{N}$ at the $\mathrm{R}_{1}$ stage, whereas nodule-fixed $\mathrm{N}$ was primarily absorbed during the $\mathrm{R}_{5}$ stage. The supplies of fertilizer $\mathrm{N}$ from the two roots of the dual root system to the Shoot were almost identical, suggesting the same supply of absorbed fertilizer $\mathrm{N}$ to Shoot by each side in the dual root system.

A comparison of Treatments I and II revealed no major change in the proportions of $\mathrm{N}$ supplied to the Shoot by each root of the dual root system, irrespective of whether $\mathrm{N}$ was added to one or both sides. However, after the addition of $\mathrm{N}$ to both sides of the root system, the proportion of nodule-fixed $\mathrm{N}$ decreased, whereas the proportions of absorbed $\mathrm{NO}_{3}^{-}$and $\mathrm{NH}_{4}^{+}$supplied to the Shoot by Root $\mathrm{non}_{\text {no }}$ and Root $_{\mathrm{n}}$ were similar.

\subsection{N Accumulation and Source in Dual Root Soybeans}

\subsubsection{N Accumulation in Dual Root Soybeans}

Table 5 shows the $\mathrm{N}$ accumulation of organs in the dual root system of single-nodule soybeans. In Treatments I, II, and III under the $\mathrm{NO}_{3}^{-} \mathrm{N}$ source for soybean plants, the $\mathrm{N}$ accumulation of Root non 
at the $R_{1}$ stage was significantly higher in Treatment III than in Treatments I and II. During the $R_{5}$ stage, there was no significant difference among Treatments I, II, or III. At the $\mathrm{R}_{1}$ stage, the $\mathrm{N}$ accumulation of Root $_{n}$ was significantly lower in Treatment I than in Treatments II and III. During the $\mathrm{R}_{5}$ stage, there was no significant difference among Treatments I, II, and III. The $\mathrm{N}$ accumulation of Nodule $_{\mathrm{n}}$ at the $\mathrm{R}_{1}$ and $\mathrm{R}_{5}$ stages was significantly higher in Treatment I than in Treatment II or III. In Treatment I, the N accumulation in the Shoot at $R_{1}$ was significantly lower than in Treatment II or III, and that at $R_{5}$ it was significantly lower than in Treatment II. The total $\mathrm{N}$ accumulation of Treatment I at the $\mathrm{R}_{1}$ stage was significantly lower than in Treatment II or III, and the difference at the $\mathrm{R}_{5}$ stage was not significant. In Treatments I, II, and III under the $\mathrm{NH}_{4}^{+} \mathrm{N}$ source for soybean plants, the $\mathrm{N}$ accumulation of Root $_{\text {non }}$ in Treatment $I$ at the $R_{1}$ and $R_{5}$ stages was significantly lower than in Treatments II and III. At the $\mathrm{R}_{1}$ stage, the $\mathrm{N}$ accumulation of Root $_{\mathrm{n}}$ in Treatment I was significantly lower than in Treatments II and III, whereas the difference was not significant at the $\mathrm{R}_{5}$ stage. The $\mathrm{N}$ accumulation of Nodule $_{n}$ in Treatment I at the $R_{1}$ and $R_{5}$ stages was significantly higher than in Treatments II and III. At the $R_{1}$ stage, the $\mathrm{N}$ accumulation in the Shoot of Treatment I was significantly lower than in Treatments II and III. The $\mathrm{R}_{1}$ and $\mathrm{R}_{5}$ stages showed the opposite pattern. In Treatment I, the $\mathrm{N}$ accumulation of the Shoot in the $\mathrm{R}_{1}$ stage was significantly lower than that in Treatments II and III, and the difference at the $\mathrm{R}_{5}$ stage was not significant.

Table 5. N accumulation in each organ of soybean in the dual root system (mg/plant).

\begin{tabular}{|c|c|c|c|c|c|c|c|}
\hline \multirow{2}{*}{ Stages } & \multirow{2}{*}{ Organs } & \multicolumn{3}{|c|}{$\mathrm{NO}_{3}^{-}$} & \multicolumn{3}{|c|}{$\mathrm{NH}_{4}^{+}$} \\
\hline & & I & II & III & I & II & III \\
\hline \multirow{5}{*}{$\mathbf{R}_{1}$} & $\operatorname{Root}_{\text {non }}$ & $18.08 \pm 1.19 c$ & $23.38 \pm 1.40 b$ & $25.20 \pm 0.77 a$ & $20.66 \pm 1.76 b$ & $25.05 \pm 1.55 a$ & $23.15 \pm 2.39 \mathrm{ab}$ \\
\hline & $\operatorname{Root}_{n}$ & $22.54 \pm 1.15 b$ & $31.19 \pm 2.71 \mathrm{a}$ & $34.53 \pm 1.30 \mathrm{a}$ & $26.52 \pm 1.00 \mathrm{~b}$ & $39.69 \pm 1.23 a$ & $38.29 \pm 1.22 \mathrm{a}$ \\
\hline & Nodule $_{n}$ & $35.79 \pm 2.34 \mathrm{a}$ & $23.28 \pm 2.63 b$ & $24.70 \pm 2.20 \mathrm{~b}$ & $33.51 \pm 0.83 a$ & $19.66 \pm 2.18 b$ & $20.94 \pm 1.87 \mathrm{~b}$ \\
\hline & Shoot & $355.50 \pm 5.98 b$ & $418.10 \pm 14.75 a$ & $432.48 \pm 7.85 a$ & $312.18 \pm 16.06 b$ & $408.87 \pm 12.33 a$ & $401.98 \pm 6.56 a$ \\
\hline & Total & $431.91 \pm 10.66 b$ & $495.95 \pm 21.49 a$ & $516.91 \pm 12.12 \mathrm{a}$ & $392.87 \pm 19.65 b$ & $493.27 \pm 17.29 a$ & $484.36 \pm 12.04 a$ \\
\hline \multirow{5}{*}{$\mathbf{R}_{5}$} & $\operatorname{Root}_{\text {non }}$ & $46.89 \pm 4.92 a$ & $41.80 \pm 4.86 \mathrm{a}$ & $37.05 \pm 4.91 \mathrm{a}$ & $37.28 \pm 0.49 b$ & $51.63 \pm 7.80 \mathrm{a}$ & $47.72 \pm 4.97 \mathrm{ab}$ \\
\hline & $\operatorname{Root}_{n}$ & $69.22 \pm 3.15 a$ & $76.83 \pm 7.06 a$ & $82.07 \pm 7.89 a$ & $68.46 \pm 6.79 a$ & $83.41 \pm 5.54 a$ & $78.15 \pm 10.63 a$ \\
\hline & Nodule $_{n}$ & $109.14 \pm 9.68 \mathrm{a}$ & $76.94 \pm 8.53 b$ & $88.15 \pm 6.63 \mathrm{ab}$ & $102.49 \pm 5.37 \mathrm{a}$ & $67.09 \pm 6.84 b$ & $72.07 \pm 7.57 \mathrm{~b}$ \\
\hline & Shoot & $1012.07 \pm 28.58 b$ & $1105.38 \pm 48.17 a$ & $1045.11 \pm 32.50 \mathrm{ab}$ & $1169.88 \pm 32.55 a$ & $1023.60 \pm 32.29 b$ & $1041.89 \pm 23.84 b$ \\
\hline & Total & $1237.32 \pm 46.33 a$ & $1300.95 \pm 68.62 a$ & $1252.38 \pm 51.93 a$ & $1378.11 \pm 45.20 \mathrm{a}$ & $1225.73 \pm 52.47 a$ & $1240.1 \pm 47.01 \mathrm{a}$ \\
\hline
\end{tabular}

The values are the means \pm standard error $(n=3)$. Different lowercase letters indicate significant differences between treatments at the $5 \%$ level. Treatments I, II, and III are compared horizontally.

A comparison of Treatments I, II, and III showed that the N accumulation of $\operatorname{Root}_{\text {non }}$ and $\operatorname{Root}_{\mathrm{n}}$ at the $\mathrm{R}_{1}$ stage in Treatment I was lower than in Treatments II and III, whereas the $\mathrm{N}$ accumulation at the $R_{5}$ stage was not significantly different among the treatments. This finding indicates that local $\mathrm{N}$ application in the early stage of soybean growth affects the accumulation of $\mathrm{N}$ in the root, but local $\mathrm{N}$ application in the late stage of soybean growth has a weak effect on the accumulation of $\mathrm{N}$ in the root, possibly because the ratio of $\mathrm{N}$ fixation in the root nodules was increasing during the late stage of soybean growth. $\mathrm{N}$ accumulation of Nodule $_{\mathrm{n}}$ in Treatment I was significantly higher than in Treatments II and III. This result indicates that the local application of $\mathrm{N}$ can inhibit the growth of root nodules on the $\mathrm{N}$-treated side and promotes the growth of root nodules on the $\mathrm{N}$-treated side, thus improving the N-fixing ability of root nodules and leading to an increase in $\mathrm{N}$ accumulation. There was no significant difference in $\mathrm{N}$ accumulation in each part of the treatment with a $\mathrm{NO}_{3}^{-} \mathrm{vs}$. $\mathrm{NH}_{4}^{+} \mathrm{N}$ source, indicating that under an $\mathrm{N}$ concentration of $50 \mathrm{mg} \cdot \mathrm{L}^{-1}$, there was no difference in the nutritional effect of $\mathrm{NO}_{3}^{-}$vs. $\mathrm{NH}_{4}^{+}$on each part.

\subsubsection{Accumulation of Fertilizer N and N-Fixing Root Nodules in Dual Root Soybeans}

As seen from Table 6, when $\mathrm{N}$ was applied on one side, the majority of Root $_{\text {non }} \mathrm{N}$ came from the fertilizer $\mathrm{N}$ absorbed by Root $_{\text {non, }}$ whereas a small part came from the root nodules of $\operatorname{Root}_{\mathrm{n}}$. When $\mathrm{N}$ was not applied to Root $_{\mathrm{n}}$, most of the $\mathrm{N}$ came from root nodule $\mathrm{N}$ fixation, and a small part came from the fertilizer $\mathrm{N}$ absorbed by Root $_{\text {non. }}$. Under unilateral $\mathrm{N}$ application to soybean roots, most of the $\mathrm{N}$ in 
Nodule $_{\mathrm{n}}$ came from the $\mathrm{N}$-fixing root nodules of Root $_{\mathrm{n}}$, and a small part came from fertilizer $\mathrm{N}$ absorbed from Root $_{\text {non, }}$ which also indicates that not all $\mathrm{N}$ needed for root nodule growth came from internal $\mathrm{N}$ fixation and some $\mathrm{N}$ needed to be absorbed from the roots. In comparing the two $\mathrm{N}$ sources in the $\mathrm{R}_{1}$ and $\mathrm{R}_{5}$ stages, $\mathrm{N}$ fixation from the root nodules was significantly higher than $\mathrm{N}$ from fertilizer $\mathrm{N}$ absorbed by Root $_{\text {non. }}$. The total $\mathrm{N}$ accumulation from $\mathrm{N}$-fixing root nodules was much higher than that from fertilizer.

Table 6. The accumulation of $\mathrm{N}$ fixation from fertilizer and nodule-fixed $\mathrm{N}$ in each parts of the dual root soybean (mg/plant).

\begin{tabular}{|c|c|c|c|c|c|c|c|c|}
\hline & \multirow[t]{2}{*}{ Stages } & \multirow[t]{2}{*}{ Organs } & \multicolumn{3}{|c|}{$\mathrm{NO}_{3}^{-}$} & \multicolumn{3}{|c|}{$\mathrm{NH}_{4}^{+}$} \\
\hline & & & ${ }^{15} \mathrm{~N}$ & \multicolumn{2}{|c|}{ Nodule } & ${ }^{15} \mathrm{~N}$ & \multicolumn{2}{|c|}{ Nodule } \\
\hline \multirow{8}{*}{ I } & \multirow{4}{*}{$\mathbf{R}_{1}$} & Root $_{n o n}$ & $13.10 \pm 0.63 a$ & \multicolumn{2}{|c|}{$4.99 \pm 0.62 b$} & $15.32 \pm 0.33 a$ & \multicolumn{2}{|c|}{$5.34 \pm 0.33 b$} \\
\hline & & Nodule $_{n}$ & $2.87 \pm 0.18 b$ & \multicolumn{2}{|c|}{$32.92 \pm 0.18 a$} & $2.64 \pm 0.11 b$ & \multicolumn{2}{|c|}{$30.88 \pm 0.11 a$} \\
\hline & & Shoot & $116.7 \pm 3.45 b$ & \multicolumn{2}{|c|}{$238.8 \pm 3.45 a$} & $109.99 \pm 1.25 b$ & \multicolumn{2}{|c|}{$202.18 \pm 1.25 a$} \\
\hline & & Total & $136.8 \pm 4.33 b$ & \multicolumn{2}{|c|}{$295.12 \pm 4.33 a$} & $133.27 \pm 1.78 \mathrm{~b}$ & \multicolumn{2}{|c|}{$259.69 \pm 1.78 \mathrm{a}$} \\
\hline & \multirow[t]{3}{*}{$\mathbf{R}_{5}$} & Nodule $_{n}$ & $4.68 \pm 0.11 b$ & \multicolumn{2}{|c|}{$104.46 \pm 0.11 a$} & $4.87 \pm 0.18 b$ & \multicolumn{2}{|c|}{$97.63 \pm 0.18 \mathrm{a}$} \\
\hline & & Shoot & $178.12 \pm 3.78 b$ & \multicolumn{2}{|c|}{$833.95 \pm 3.78 \mathrm{a}$} & $222.20 \pm 4.69 \mathrm{~b}$ & \multicolumn{2}{|c|}{$947.67 \pm 4.69 \mathrm{a}$} \\
\hline & & Total & $220.58 \pm 5.54 b$ & \multicolumn{2}{|c|}{$1016.75 \pm 5.54 a$} & $261.15 \pm 7.59 b$ & \multicolumn{2}{|c|}{$1116.94 \pm 7.59 a$} \\
\hline & Stages Org & gans & ${ }^{15} \mathrm{~N}$ & ${ }^{14} \mathrm{~N}$ & Nodule & ${ }^{15} \mathrm{~N}$ & ${ }^{14} \mathrm{~N}$ & Nodule \\
\hline \multirow{6}{*}{ II } & $\mathbf{R}_{\mathbf{1}}$ & Total & $146.74 \pm 7.72 b$ & $125.01 \pm 6.97 \mathrm{c}$ & $224.20 \pm 3.71 \mathrm{a}$ & $145.15 \pm 2.77 \mathrm{c}$ & $158.82 \pm 3.68 b$ & $189.30 \pm 3.61 \mathrm{a}$ \\
\hline & \multirow{5}{*}{$\mathbf{R}_{\mathbf{5}}$} & Root $_{\text {non }}$ & $24.45 \pm 1.08 \mathrm{a}$ & $5.94 \pm 1.10 c$ & $11.41 \pm 0.07 \mathrm{~b}$ & $33.35 \pm 1.77 a$ & $4.54 \pm 0.37 c$ & $13.73 \pm 1.40 b$ \\
\hline & & $\operatorname{Root}_{n}$ & $9.37 \pm 0.67 c$ & $25.97 \pm 2.02 b$ & $41.49 \pm 1.94 a$ & $8.51 \pm 0.79 c$ & $32.86 \pm 0.43 b$ & $42.04 \pm 1.17 a$ \\
\hline & & Nodule $_{n}$ & $3.62 \pm 0.32 c$ & $5.54 \pm 0.35 b$ & $67.78 \pm 0.03 a$ & $3.09 \pm 0.19 c$ & $4.83 \pm 0.02 b$ & $59.17 \pm 0.21 a$ \\
\hline & & Shoot & $194.55 \pm 8.10 \mathrm{~b}$ & $169.12 \pm 10.64 c$ & $741.71 \pm 8.15 a$ & $202.67 \pm 5.96 b$ & $187.32 \pm 5.90 c$ & $633.61 \pm 9.24 a$ \\
\hline & & Total & $231.99 \pm 10.17 b$ & $206.57 \pm 14.11 \mathrm{c}$ & $862.39 \pm 10.19 a$ & $247.62 \pm 8.71 b$ & $229.55 \pm 6.72 b$ & $748.55 \pm 12.02 a$ \\
\hline
\end{tabular}

In the dual root system, Root $_{\text {non }}$ represents non-nodulated roots, Root $_{n}$ represents nodulated roots, and Nodule $_{n}$ represents nodules on the same side as the nodulated roots. ${ }^{15} \mathrm{~N}$ represents the $\mathrm{N}$ accumulation of ${ }^{15} \mathrm{~N}-\mathrm{labeled}$ fertilizer $N,{ }^{14} \mathrm{~N}$ represents the $\mathrm{N}$ accumulation of unlabeled fertilizer $\mathrm{N}$, and Nodule represents the $\mathrm{N}$ accumulation of nodule-fixed N. The values are the means \pm standard error $(n=3)$. Different lowercase letters indicate significant differences between treatments at the $5 \%$ level. The three $\mathrm{N}$ sources are compared horizontally.

Under the condition of bilateral $\mathrm{N}$ application, most of the $\mathrm{N}$ in Root $_{\text {non }}$ came from the fertilizer $\mathrm{N}$ absorbed by Root $_{\text {non, }}$ and a small part came from the $\mathrm{N}$ absorbed and fixed by Root $_{\mathrm{n}}$. However, most of the $\mathrm{N}$ in Root $_{n}$ came from the $\mathrm{N}$ absorbed and fixed by Root ${ }_{n}$, whereas a small part came from the fertilizer $\mathrm{N}$ absorbed by Root ${ }_{n o n}$ and transferred to Root $_{\mathrm{n}}$. Most of the $\mathrm{N}$ in Nodule $_{\mathrm{n}}$ came from $\mathrm{N}$ absorbed and fixed by Root $_{\mathrm{n}}$, and a small part came from fertilizer $\mathrm{N}$ absorbed by Root $\mathrm{t}_{\text {non }}$ and transferred to Root $_{n}$ nodules. At the same time, it can be observed that not all the $\mathrm{N}$ required for root nodule growth comes from self-fixing $\mathrm{N}$, and it is also necessary to absorb $\mathrm{N}$ via the roots. In comparing the three $\mathrm{N}$ sources in the Shoot at the $\mathrm{R}_{1}$ and $\mathrm{R}_{5}$ stages, there was no significant difference between $\mathrm{N}$ accumulation in $\operatorname{Root}_{\text {non }}$ and $\operatorname{Root}_{n}$, but $\mathrm{N}$ accumulation was significantly lower than in the N-fixing root nodules of Root $_{n}$. This suggests that the supply of absorbed fertilizer $\mathrm{N}$ to Shoot was the same from the two parts of the dual root systems. As a whole, the total accumulation of $\mathrm{N}$ absorbed and fixed by Root $_{\mathrm{n}}$ was much higher than the fertilizer $\mathrm{N}$ absorbed by Root ${ }_{\text {non, }}$, mainly because Root non $_{\text {n }}$ had no root nodules for $\mathrm{N}$ fixation. 


\subsubsection{N Translocation from Shoot to Roots and Nodules of Soybeans}

The fertilizer $\mathrm{N}$ absorbed by the two roots of the dual root system and the $\mathrm{N}$ fixed by the root nodules were transported to the Shoot, and after assimilation, they were transported to the roots and nodules in certain forms. Due to the different ${ }^{15} \mathrm{~N}$ abundance in various parts of the soybean plants in the treatments (Table 2), we regarded the Root $_{n}$ and the Shoot as one system, in which the Shoot served as a source of ${ }^{15} \mathrm{~N}$ for the Root ${ }_{n}$. From the $R_{1}$ to the $R_{5}$ stage, the amount of ${ }^{15} \mathrm{~N}$ increasing in Root $_{n}$ can be obtained from the ${ }^{15} \mathrm{~N}$ accumulation of the $R_{5}$ stage minus the ${ }^{15} \mathrm{~N}$ accumulation of the $\mathrm{R}_{1}$ stage, and this should be equal to the amount of ${ }^{15} \mathrm{~N}$ translocated from the Shoot plus the amount of naturally occurring ${ }^{15} \mathrm{~N}$ that was self-absorbed by the roots of Root $_{n}$ (including the supply by nodules) from the $\mathrm{R}_{1}$ to the $\mathrm{R}_{5}$ stage. If we let the amount of $\mathrm{N}$ translocated from the Shoot to $\operatorname{Root}_{\mathrm{n}}$ be $x$, then the ${ }^{15} \mathrm{~N}$ abundance of the $\mathrm{N}$ translocated downwards from the Shoot can be calculated using the mean ${ }^{15} \mathrm{~N}$ abundance in the Shoot at the $\mathrm{R}_{1}$ and $\mathrm{R}_{5}$ stages, where $x \times\left(\mathrm{f}_{\text {shootR } 1}+\mathrm{f}_{\text {shootR } 5}\right) / 2$ represents the amount of ${ }^{15} \mathrm{~N}$ translocated from the Shoot to Root $_{n}$ during $\mathrm{R}_{1}-\mathrm{R}_{5}, \mathrm{~N}_{\mathrm{R} 5}-\mathrm{N}_{\mathrm{R} 1}$ represents the $\mathrm{N}$ accumulation in Root $_{n}$ during $\mathrm{R}_{1}-\mathrm{R}_{5}, \mathrm{~N}_{\mathrm{R} 1}-\mathrm{N}_{\mathrm{R} 5}-x$ represents the $\mathrm{N}$ accumulation from Root $_{\mathrm{n}}$ absorbed during $\mathrm{R}_{1}-\mathrm{R}_{5}$ (including the $\mathrm{N}$ supplied by nodules), $\left(\mathrm{N}_{\mathrm{R} 5}-\mathrm{N}_{\mathrm{R} 1}-x\right) \times \mathrm{f}_{\text {nature }}$ represents the amount of ${ }^{15} \mathrm{~N}$ in Root $_{n}$ that is self-absorbed by the roots and supplied by the nodules during $R_{1}-R_{5}, N_{R 5} \times f_{R 5}$ represents the total ${ }^{15} \mathrm{~N}$ in Root $_{n}$ at the $\mathrm{R}_{5}$ stage, and $\mathrm{N}_{\mathrm{R} 1} \times \mathrm{f}_{\mathrm{R} 1}$ represents the total ${ }^{15} \mathrm{~N}$ in $\operatorname{Root}_{n}$ at the $\mathrm{R}_{1}$ stage. This method can also be used to calculate the amount of $N$ translocated from the Shoot to Nodule e $_{n}$. For Treatments I and II, the calculation is as follows:

$$
\begin{gathered}
x \times\left(\mathrm{f}_{\text {shootR } 1}+\mathrm{f}_{\text {shootR } 5}\right) / 2+\left(\mathrm{N}_{\mathrm{R} 5}-\mathrm{N}_{\mathrm{R} 1}-x\right) \times \mathrm{f}_{\text {nature }}=\mathrm{N}_{\mathrm{R} 5} \times \mathrm{f}_{\mathrm{R} 5}-\mathrm{N}_{\mathrm{R} 1} \times \mathrm{f}_{\mathrm{R} 1} \\
x=\frac{\mathrm{N}_{\mathrm{R} 5} \times \mathrm{f}_{\mathrm{R} 5}-\mathrm{N}_{\mathrm{R} 1} \times \mathrm{f}_{\mathrm{R} 1}-\left(\mathrm{N}_{\mathrm{R} 5}-\mathrm{N}_{\mathrm{R} 1}\right) \times \mathrm{f}_{\text {nature }}}{\left(\mathrm{f}_{\text {shootR } 1}+\mathrm{f}_{\text {shootR5 }}\right) / 2-\mathrm{f}_{\text {nature }}}
\end{gathered}
$$

where $x$ is the amount of $\mathrm{N}$ translocated from the Shoot to Root or Nodule $_{n}, \mathrm{~N}_{\mathrm{R} 1}$ is the $\mathrm{N}$ accumulation in $\operatorname{Root}_{n}$ or Nodule at the $\mathrm{R}_{1}$ stage, $\mathrm{N}_{\mathrm{R} 5}$ is the $\mathrm{N}$ accumulation in $\operatorname{Root}_{\mathrm{n}}$ or Nodule $\mathrm{n}$ at the $\mathrm{R}_{5}$ stage, $f_{\text {nature }}$ is the natural ${ }^{15} \mathrm{~N}$ abundance, $\mathrm{f}_{\mathrm{R} 1}$ is the ${ }^{15} \mathrm{~N}$ abundance in $\operatorname{Root}_{\mathrm{n}}$ or Nodule $\mathrm{n}$ at the $\mathrm{R}_{1}$ stage, $\mathrm{f}_{\mathrm{R} 5}$ is the ${ }^{15} \mathrm{~N}$ abundance in Root $_{n}$ or Nodule $n$ at the $R_{5}$ stage, $f_{\text {shootR1 }}$ is the ${ }^{15} \mathrm{~N}$ abundance in the Shoot at the $R_{1}$ stage, and $f_{\text {shootR5 }}$ is the ${ }^{15} \mathrm{~N}$ abundance in the Shoot at the $R_{5}$ stage.

Similarly, when calculating the amount of $\mathrm{N}$ translocated from the Shoot to Root ${ }_{\text {non }}$, we regarded the Root $_{\text {non }}$ and the Shoot as one system. Because ${ }^{15} \mathrm{~N}$-labeled fertilizer N was added to Root non, $_{\text {, }}$ the calculation is as follows:

$$
\begin{gathered}
x \times\left(\mathrm{f}_{\text {shootR } 1}+\mathrm{f}_{\text {shootR } 5}\right) / 2+\left(\mathrm{N}_{\mathrm{R} 5}-\mathrm{N}_{\mathrm{R} 1}-x\right) \times \mathrm{f}_{\text {fertilizer }}=\mathrm{N}_{\mathrm{R} 5} \times \mathrm{f}_{\mathrm{R} 5}-\mathrm{N}_{\mathrm{R} 1} \times \mathrm{f}_{\mathrm{R} 1} \\
x=\frac{\left(\mathrm{N}_{\mathrm{R} 5}-\mathrm{N}_{\mathrm{R} 1}\right) \times \mathrm{f}_{\text {fertilizer }}-\mathrm{N}_{\mathrm{R} 5} \times \mathrm{f}_{\mathrm{R} 5}+\mathrm{N}_{\mathrm{R} 1} \times \mathrm{f}_{\mathrm{R} 1}}{\mathrm{f}_{\text {fertilizer }}-\left(\mathrm{f}_{\text {shootR} 1}+\mathrm{f}_{\text {shootR } 5}\right) / 2}
\end{gathered}
$$

where $x$ is the amount of $\mathrm{N}$ translocated from the Shoot to Root $_{n o n}, \mathrm{~N}_{\mathrm{R} 1}$ is the $\mathrm{N}$ accumulation in Root $_{n o n}$ at the $R_{1}$ stage, $N_{R 5}$ is the $N$ accumulation in Root ${ }_{\text {non }}$ at the $R_{5}$ stage, $f_{\text {fertilizer }}$ is the ${ }^{15} \mathrm{~N}$ abundance in the fertilizer, $\mathrm{f}_{\mathrm{R} 1}$ is the ${ }^{15} \mathrm{~N}$ abundance in Root $_{\text {non }}$ at the $\mathrm{R}_{1}$ stage, $\mathrm{f}_{\mathrm{R}}$ is the ${ }^{15} \mathrm{~N}$ abundance in Root $t_{n o n}$ at the $R_{5}$ stage, $f_{\text {shootR } 1}$ is the ${ }^{15} \mathrm{~N}$ abundance in the Shoot at the $R_{1}$ stage, and $f_{\text {shootR5 }}$ is the ${ }^{15} \mathrm{~N}$ abundance in the Shoot at the $\mathrm{R}_{5}$ stage.

The amount of $\mathrm{N}$ translocated from the Shoot to Root ${ }_{\text {non }}$, Root $_{\mathrm{n}}$, and Nodule $\mathrm{n}$ can be calculated using Equations (4) and (5), as shown in Table 7. 
Table 7. $\mathrm{N}$ translocation from the Shoot to roots and nodules of soybean plants from the $\mathrm{R}_{1}-\mathrm{R}_{5}$ stage.

\begin{tabular}{|c|c|c|c|c|c|c|c|}
\hline & \multirow{2}{*}{ Organs } & \multicolumn{3}{|c|}{$\mathrm{NO}_{3}^{-}$} & \multicolumn{3}{|c|}{$\mathrm{NH}_{4}^{+}$} \\
\hline & & $\begin{array}{c}\text { NIA } \\
\text { (mg/plant) }\end{array}$ & $\begin{array}{c}\text { NTFS } \\
\text { (mg/plant) }\end{array}$ & $\begin{array}{c}\text { NTFS/NIA } \\
(\%)\end{array}$ & $\begin{array}{c}\text { NIA } \\
\text { (mg/plant) }\end{array}$ & $\begin{array}{c}\text { NTFS } \\
\text { (mg/plant) }\end{array}$ & $\begin{array}{c}\text { NTFS/NIA } \\
(\%)\end{array}$ \\
\hline \multirow{4}{*}{ I } & Root $_{\text {non }}$ & 28.8 & 16.1 & 55.9 & 16.6 & 9.5 & 57.0 \\
\hline & $\operatorname{Root}_{n}$ & 46.8 & 13.9 & 29.6 & 41.9 & 14.6 & 34.9 \\
\hline & Nodule $_{n}$ & 73.4 & 6.9 & 9.4 & 68.9 & 8.4 & 12.2 \\
\hline & Total & 148.9 & 36.9 & 24.8 & 127.4 & 32.5 & 25.5 \\
\hline \multirow{4}{*}{ II } & Root $_{\text {non }}$ & 18.4 & 13.0 & 70.5 & 26.6 & 13.8 & 51.8 \\
\hline & $\operatorname{Root}_{\mathrm{n}}$ & 45.7 & 22.9 & 50.0 & 43.6 & 17.6 & 40.3 \\
\hline & Nodule $_{n}$ & 53.7 & 8.9 & 16.6 & 47.5 & 7.3 & 15.3 \\
\hline & Total & 117.7 & 44.8 & 38.1 & 117.6 & 38.7 & 32.9 \\
\hline
\end{tabular}

In the dual root system, Root $_{n}$ represents nodulated roots, Root ${ }_{n o n}$ represents non-nodulated roots, and Nodule $\mathrm{n}_{\mathrm{n}}$ represents nodules on the same side as the nodulated roots. ANT $(\mathrm{mg})$ represents the accumulation of $\mathrm{N}$ translocated from the Shoot to roots and nodules during $R_{1}-R_{5}$, AIN $(\mathrm{mg})$ represents the accumulation of increased $N$ in various parts during $R_{1}-R_{5}$, and ANT/AIN (\%) represents the proportion of total $N$ from Shoot (NTFS) under AIN in various plant parts.

Table 7 shows that for Treatment $\mathrm{I}$, in the $\mathrm{NO}_{3}^{-}$and $\mathrm{NH}_{4}^{+} \mathrm{N}$ sources between the $\mathrm{R}_{1}$ and $\mathrm{R}_{5}$ stages, the accumulation of increased $\mathrm{N}$ in Root $_{\text {non }}$ was 28.8 and $16.6 \mathrm{mg}$, respectively, and the accumulation of $\mathrm{N}$ translocated from the Shoot to Root ${ }_{\text {non }}$ was 16.1 and $9.5 \mathrm{mg}$, respectively. The $\mathrm{N}$ translocated from the Shoot to Root $_{\text {non }}$ accounted for $55.9 \%$ and $57.0 \%$, respectively, of the increased accumulation of $\mathrm{N}$ in Root non. $_{\text {. In Root }}$, the increased accumulation of $\mathrm{N}$ was 46.8 and $41.9 \mathrm{mg}$, respectively, and the accumulation of $\mathrm{N}$ translocated from the Shoot was 13.9 and $14.6 \mathrm{mg}$, accounting for $29.6 \%$ and $34.9 \%$, respectively, of the increased accumulation of $\mathrm{N}$ in $\operatorname{Root}_{\mathrm{n}}$. In Nodule $\mathrm{n}$, the increased accumulation of $\mathrm{N}$ was 73.4 and $68.9 \mathrm{mg}$, respectively, and the accumulation of $\mathrm{N}$ translocated from the Shoot was 6.9 and $8.3 \mathrm{mg}$, contributing to $9.4 \%$ and $12.2 \%$, respectively, of the increased accumulation of $\mathrm{N}$ in Nodule $n$. In Treatment II with $\mathrm{NO}_{3}^{-}$and $\mathrm{NH}_{4}^{+} \mathrm{N}$ sources between the $\mathrm{R}_{1}$ and $\mathrm{R}_{5}$ stages, the increased accumulation of $\mathrm{N}$ in Root $_{\text {non }}$ was 18.4 and $26.6 \mathrm{mg}$, respectively, and the accumulation of $\mathrm{N}$ translocated from the Shoot to Root $_{\text {non }}$ was 13.0 and $13.8 \mathrm{mg}$, making up 70.5\% and 51.8\%, respectively, of the increased accumulation of $\mathrm{N}$ in Root $_{\text {non. }}$. In Root $\mathrm{n}_{\mathrm{n}}$, the increased accumulation of $\mathrm{N}$ was 45.7 and $43.6 \mathrm{mg}$, respectively, and the accumulation of $\mathrm{N}$ translocated from the Shoot was 22.9 and $17.6 \mathrm{mg}$, accounting for $50.0 \%$ and $40.3 \%$, respectively, of the increased accumulation of $\mathrm{N}$ in Root $_{\mathrm{n}}$. In Nodule $\mathrm{n}$, the increased accumulation of $\mathrm{N}$ was 53.7 and $47.5 \mathrm{mg}$, respectively, and the accumulation of $\mathrm{N}$ translocated from the Shoot was 8.9 and $7.3 \mathrm{mg}$, contributing to only $16.6 \%$ and $15.3 \%$, respectively, of the increased accumulation of $\mathrm{N}$ in Nodule $_{\mathrm{n}}$.

\section{Discussion}

\subsection{Sources of $N$ in the Roots and Nodules of Soybeans}

After adding ${ }^{15} \mathrm{NO}_{3}^{-}$to soybean (Glycine max L. Merr.) seedlings, Crafts-Brandner and Harper [35] detected ${ }^{15} \mathrm{~N}$ in the reduced $\mathrm{N}$ from xylem sap and found that the ${ }^{15} \mathrm{~N}$ abundance tended to increase with time, leading to a conclusion that soybean roots can reduce ${ }^{15} \mathrm{NO}_{3}^{-}$. Sprent and Thomas [36] indicated that Phaseolus vulgaris and Glycine max directly absorb and transport fertilizer $\mathrm{NO}_{3}^{-}$into the shoots for assimilation, whereas Pisum sativum and Vicia faba transport $\mathrm{NO}_{3}^{-}$into the shoots after assimilation in the roots. Following the application of different concentrations of $\mathrm{NO}_{3}^{-}$to six leguminous crops, Andrews [37] found that the assimilation of absorbed $\mathrm{NO}_{3}^{-}$occurred primarily in the roots of Cajanus cajan, Lupinus albus, Trifolium repens, and Pisum sativum, whereas Glycine max, and Phaseolus vulgaris primarily assimilated the absorbed $\mathrm{NO}_{3}^{-}$in the shoots. Kiyomiya et al. [38] treated the roots of rice with ${ }^{13} \mathrm{NH}_{4}^{+}$and then observed the ${ }^{13} \mathrm{~N}$ at the bottoms of the shoots within 2 min. However, the rapid upward transport of ${ }^{13} \mathrm{~N}$ was inhibited after the addition of glutamine synthetase inhibitor, indicating that most of the $\mathrm{NH}_{4}^{+}$was assimilated in the roots. In the present study, under ${ }^{15} \mathrm{NO}_{3}^{-}$and 
${ }^{15} \mathrm{NH}_{4}^{+}$treatments, the ${ }^{15} \mathrm{~N}$ abundance in the roots on the $\mathrm{N}$-receiving side was always higher than in the shoots, indicating that part of the ${ }^{15} \mathrm{NO}_{3}^{-}$and ${ }^{15} \mathrm{NH}_{4}^{+}$absorbed by the roots was used for root growth after assimilation in the roots (otherwise, if all the absorbed fertilizer $\mathrm{N}$ was transported to the shoots for assimilation, the ${ }^{15} \mathrm{~N}$ abundance would have been the same in both the shoots and roots). Tanaka et al. [9] and Reynolds et al. [31] established split-root system in soybeans and added ${ }^{15} \mathrm{NO}_{3}^{-}$ and ${ }^{13} \mathrm{NH}_{4}^{+}$to one side of the roots, and they then detected the ${ }^{15} \mathrm{~N}$ and ${ }^{13} \mathrm{~N}$ in the roots and nodules on the $\mathrm{N}$-free side. In the present study, we added ${ }^{15} \mathrm{~N}$-labeled fertilizer $\mathrm{N}$ to non-nodulated roots on one side of the dual root system, and yet a ${ }^{15} \mathrm{~N}$ concentration higher than the natural abundance was detected in both the nodulated roots and root nodules on the other side. This finding indicates that the $\mathrm{N}$ absorbed by the roots on one side was translocated to the roots and nodules on the other side via the Shoot.

Sato et al. [39] added ${ }^{13} \mathrm{NO}_{3}^{-}$to the culture nutrient solution of nodulated soybeans and then recorded data at 1-min intervals for $1 \mathrm{~h}$. They found that ${ }^{13} \mathrm{~N}$-labeled $\mathrm{NO}_{3}^{-}$first appeared in soybean petioles and then in the leaves, with little detected in the nodules. This observation suggests that the $\mathrm{NO}_{3}^{-}$absorbed by the roots was not translocated into the nodules within a short period of time. In Treatments I and II, we added ${ }^{15} \mathrm{~N}$-labeled fertilizer $\mathrm{N}$ to non-nodulated roots in the dual root system, and yet a higher ${ }^{15} \mathrm{~N}$ was detected in the nodules on the other side than would be naturally available $(0.365 \%)$. By combining these findings with the results of Sato et al. [39], we believe that the absorbed fertilizer N present in the nodules was translocated from the Shoot, rather than directly absorbed and supplied by the roots. In Treatment III, we added the same concentration of ${ }^{15} \mathrm{~N}$-labeled fertilizer $\mathrm{N}$ to both sides of the dual root system. The ${ }^{15} \mathrm{~N}$ abundance in $\operatorname{Root}_{\text {non }}$ was higher than that in $\operatorname{Root}_{\mathrm{n}}$ at both the $R_{1}$ and $R_{5}$ stages, reflecting that nodule-fixed $N$ was directly supplied to Root $_{n}$ and nodule growth.

Wery et al. [40] conducted an experiment using alfalfa with and without $\mathrm{NH}_{4}^{+}$addition, and no significant difference was found in $\mathrm{N}$ accumulation between the two treatments. However, with an $\mathrm{N}$ supply, the rate of $\mathrm{N}$ fixation in the nodules decreased, whereas the absorbed $\mathrm{N}$ increased. This phenomenon indicates that alfalfa preferentially selected combined $\mathrm{N}$ in the presence of both combined $\mathrm{N}$ and $\mathrm{N}_{2}$. In Treatment I, $50 \mathrm{mg} \cdot \mathrm{L}^{-1} \mathrm{~N}$ was supplied to Root ${ }_{\text {non, }}$ and in Treatment II, there was a bilateral supply of $50 \mathrm{mg} \cdot \mathrm{L}^{-1} \mathrm{~N}$ to Root $_{\text {non }}$ and Root $_{\mathrm{n}}$. It was found that the ratio of Root $_{\mathrm{n}}$ $\mathrm{N}$ supplied to aboveground $\mathrm{N}$ supply at the $\mathrm{R}_{1}$ and $\mathrm{R}_{5}$ stages was similar, but the proportion of nodule-fixed $\mathrm{N}$ supplied to aboveground $\mathrm{N}$ supply in root nodules was smaller; this further indicates that the fertilizer $\mathrm{N}$ was preferentially selected by soybeans in the presence of a fertilizer $\mathrm{N}$ supply.

Many researchers believe that $\mathrm{N}$ application can considerably increase soybean yields [1-4], yet there are divergent opinions regarding the differences in the effects of $\mathrm{NO}_{3}^{-}$and $\mathrm{NH}_{4}^{+}$on plants. In a study using the soybean split-root system, Chaillou et al. [41] found that the dry weight of the roots on one side that received $\mathrm{NO}_{3}^{-}$was higher than on the other side that received $\mathrm{NH}_{4}^{+}$. However, Gan et al. [23] treated soybeans with $\mathrm{NO}_{3}^{-}$and $\mathrm{NH}_{4}^{+}$and found that $\mathrm{NH}_{4}^{+}$application alone resulted in a higher biomass accumulation, nodule dry weight, total $\mathrm{N}$ accumulation, and $\mathrm{N}$ fixation in this crop. Saravitz et al. [42] found that when $\mathrm{NH}_{4}^{+}$and $\mathrm{NO}_{3}^{-}$were applied to the dual roots of soybean, the cumulative absorption of $\mathrm{NH}_{4}^{+}$was about half that of $\mathrm{NO}_{3}^{-}$. Abdellaoui et al. [43] believed that both $\mathrm{NH}_{4}^{+}$and $\mathrm{NO}_{3}^{-}$were easily absorbed by the root system in wheat seedlings, but only $\mathrm{NO}_{3}^{-}$could accumulate in plants. The phloem in the root of the castor oil plant only absorbs $\mathrm{NO}_{3}^{-}$, not ammonium salt, and $\mathrm{NO}_{3}^{-}$is rapidly transported in xylem [44]. Although plants can effectively use $\mathrm{NH}_{4}^{+}$, it is generally considered that $\mathrm{NO}_{3}^{-}$is the main absorption form of plant $\mathrm{N}$, mainly because $\mathrm{NO}_{3}^{-}$is more soluble [45]. Savvas et al. [46] found that $\mathrm{NH}_{4}^{+}$could be nitrated in both soil and a hydroponic nutrient solution and that $\mathrm{NO}_{3}^{-}$could be formed by nitration even when $\mathrm{NH}_{4}^{+}$was supplied. Kumar [47] suggested that $\mathrm{NH}_{4}^{+}$was more easily converted into $\mathrm{NO}_{3}^{-}$in soils with good ventilation. In this experiment, no significant differences were observed in the ${ }^{15} \mathrm{~N}$ abundance or $\mathrm{N}$ accumulation in various parts of the soybean plants after $\mathrm{NO}_{3}^{-}$and $\mathrm{NH}_{4}^{+}$treatments, indicating that there were no major differences in the effects of $\mathrm{NO}_{3}^{-}$and $\mathrm{NH}_{4}^{+}$on $\mathrm{N}$ nutrition in soybeans under the experimental conditions (50 mg. $\mathrm{L}^{-1} \mathrm{~N}$ addition). This may be because $\mathrm{NH}_{4}^{+}$was nitrated to $\mathrm{NO}_{3}^{-}$. 


\subsection{N Distribution in Shoot, Roots, and Nodules of Soybean Plants}

In this study, a significantly higher $\mathrm{N}$ accumulation was observed in the Shoot than in the roots and nodules of soybeans (Table 6), suggesting that the $\mathrm{N}$ absorbed by the roots and fixed by the nodules was primarily transported to the aboveground part for Shoot growth, with only a small fraction supplied to the roots and nodules growth. After adding ${ }^{15} \mathrm{NO}_{3}^{-}$or ${ }^{15} \mathrm{NH}_{4}^{+}$to the leaf surface of sunflower, Ito, $\mathrm{O}$. et al. [48] determined the ${ }^{15} \mathrm{~N}$ abundance in $\mathrm{N}$-treated leaves and their upper and lower internodes. ${ }^{15} \mathrm{~N}$ was detected in both the upper and lower internodes, with a lower value for the upper than for the lower internode, revealing that the $\mathrm{N}$ added to the leaf surface can be transported not only upwards but also downwards and that the downward transport exceeds the upward transport. Tanaka et al. [9], Reynolds et al. [31], and our present study have all demonstrated that the $\mathrm{N}$ absorbed by roots on one side was transferred to the roots and nodules on the other side through the shoots, suggesting that the $\mathrm{N}$ assimilated by shoots can be translocated and redistributed to the roots and nodules.

In this study, using the Shoot and one side of the roots and nodules in the dual root system as an $\mathrm{N}$ translocation system, we established a method for calculating the translocation of $\mathrm{N}$ from the Shoot to the roots and nodules during the $R_{1}-R_{5}$ stages based on the difference in ${ }^{15} \mathrm{~N}$ abundance. The calculation showed that when $\mathrm{N}$ was added at a concentration of $50 \mathrm{mg} \cdot \mathrm{L}^{-1}$, the $\mathrm{N}$ translocated from the Shoot to $\operatorname{Root}_{n}$ accounted for $29.6 \%-52.3 \%$ of the N accumulation in $\operatorname{Root}_{n}$, whereas the $\mathrm{N}$ translocated from the Shoot to Nodule $_{\mathrm{n}}$ made up $9.4 \%-16.6 \%$ of the $\mathrm{N}$ accumulation in Nodule $_{\mathrm{n}}$ during the $\mathrm{R}_{1}-\mathrm{R}_{5}$ stage. In the dual root system, the $\mathrm{N}$ absorbed and fixed by Root $_{\mathrm{n}}$ and Nodule $_{\mathrm{n}}$ was absorbed and utilized by the aboveground part whereas the fertilizer $\mathrm{N}$ was absorbed by Root non $_{\text {. }}$. After the assimilation by the aboveground part, the $\mathrm{N}$ can be transported to the root and root nodules in a certain form.

\section{Conclusions}

1. Up to $81.5 \%-87.1 \%$ of the $\mathrm{N}$ absorbed by the soybean roots and fixed by the root nodules was supplied for shoot growth, leaving $12.9 \%-18.5 \%$ for root and nodule growth. Soybeans preferentially used fertilizer $\mathrm{N}$ in the presence of the $\mathrm{NO}_{3}^{-}$or $\mathrm{NH}_{4}^{+}$supply. After the absorbed fertilizer $\mathrm{N}$ and nodule-fixed $\mathrm{N}$ was transported to the shoot, a portion of it was redistributed to the roots and nodules. The nitrogen required for root growth was primarily derived from the $\mathrm{NO}_{3}^{-}$or $\mathrm{NH}_{4}^{+}$assimilated by the roots and the $\mathrm{N}$ fixed by the nodules, with a small portion translocated from the shoot. The $\mathrm{N}$ required for nodule growth was primarily contributed by nodule-fixed $\mathrm{N}$ with a small portion translocated from the shoot, whereas the $\mathrm{NO}_{3}^{-}$or $\mathrm{NH}_{4}^{+}$assimilated by the roots was not directly supplied to the nodules.

2. Using the shoot and one side of the roots and nodules in the dual root system as an $\mathrm{N}$ translocation system, we established a method for calculating the translocation of $\mathrm{N}$ from the shoots to the roots and nodules during the $\mathrm{R}_{1}-\mathrm{R}_{5}$ stages based on the difference in ${ }^{15} \mathrm{~N}$ abundance. The calculation showed that when $\mathrm{N}$ was added at a concentration of $50 \mathrm{mg} \cdot \mathrm{L}^{-1}$, the $\mathrm{N}$ translocated from the Shoot to Root $_{n}$ accounted for $29.6 \%-52.3 \%$ of the $\mathrm{N}$ accumulation in Root $_{n}$, whereas the $\mathrm{N}$ translocated from the Shoot to Nodule $n$ made up $9.4 \%-16.6 \%$ of the $\mathrm{N}$ accumulation in Nodule $\mathrm{n}_{\mathrm{n}}$ during the $\mathrm{R}_{1}-\mathrm{R}_{5}$ stage.

3. This experiment systematically studied the transport characteristics of soybean $\mathrm{N}$ and the interaction mechanism of fertilizer $\mathrm{N}$ and root nodule $\mathrm{N}$ fixation, providing a theoretical basis and guidance for the rational application of $\mathrm{N}$ fertilizer.

Author Contributions: Conceptualization, Z.G. and X.L.; Data curation, W.T.; Funding acquisition, C.M. and Z.G.; Investigation, S.D.; Methodology, J.W. and S.K.; Resources, C.M.; Software, C.W.; Writing - original draft, R.Z.; Writing - review \& editing, R.Z. and J.W. All authors have read and agreed to the published version of the manuscript.

Funding: We are grateful for the support from the National Key Research and Development Programme, Physiology and Regulation of High Quality Soybean Production (Grant Number: 2018YFD1000905) and by Research and Demonstration on the Key Technology of High Yield and High Efficiency of Soybean (Grant Number: GA19B101). 
Conflicts of Interest: The authors declare no conflicts of interest.

\section{References}

1. Taylor, R.S.; Weaver, D.B.; Wood, C.; van Santen, E. Nitrogen Application Increases Yield and Early Dry Matter Accumulation in Late-Planted Soybean. Crop Sci. 2005, 45. [CrossRef]

2. Mahon, J.D.; Child, J.J. Growth response of inoculated peas (Pisum sativum) to combined nitrogen. Can. J. Bot. 1979, 57, 1687-1693. [CrossRef]

3. Ranđelović, V.; Prodanović, S.; Tomić, Z.; Bijelić, Z. Genotypic response of two soybean varieties with reduced content of KTI to application of different nitrogen level. Biotechnol. Anim. Husb. 2010. [CrossRef]

4. Đukić, V.; Đorđević, V.; Popović, V.; Balešević-Tubić, S.; Petrović, K.; Jakšić, S.; Dozet, G. Effect of nitrogen and Nitragin application on soybean yield and protein content. Ratar. Povrt. 2010, 47, 187-192.

5. Wang, C.B.; Zheng, Y.M.; Shen, P.; Zheng, Y.P.; Wu, Z.F.; Sun, X.W.; Yu, T.Y.; Feng, H. Dterming N supplied sources and $\mathrm{N}$ use efficiency for peanut under applications of four forms of $\mathrm{N}$ fertilizers labeled by isotope ${ }^{15}$ N. J. Integerative Agric. 2016, 15, 432-439. [CrossRef]

6. Conejero, G.; Tirado, J.L.; Robin, P. Effect of nodulation on the nitrate assimilation in vegetative soybean plants. Plant Soil 1986, 91, 385-389. [CrossRef]

7. Saito, A.; Tanabata, S.; Tanabata, T. Effect of Nitrate on Nodule and Root Growth of Soybean(Glycine max (L.)Merr.). Int. J. Mol. Sci. 2014, 15, 4464-4480. [CrossRef]

8. Hinson, K. Nodulation Responses from Nitrogen Applied to Soybean Half-Root Systems. Agron. J. 1975, 67, 799-804. [CrossRef]

9. Tanaka, A.; Fujlta, K.; Terasawa, H. Growth and Dinitrogen Fixation, of Soybean Root System Affected by Partial Exposure to Nitrate. Soil Sci. Plant Nutr. 1985, 31, 637-645. [CrossRef]

10. Carroll, B.J.; Gresshoff, P.M. Nitrate Inhibition of Nodulation and Nitrogen Fixation in White Clover. Z. Pflanzenphysiol. 1981, 110,77-88. [CrossRef]

11. Daimon, H.; Yoshioka, M. Responses of Root Nodule Formation and Nitrogen Fixation Activity to Nitrate in a Split-Root System in Peanut (Arachis hypogaea L). J. Agron. Crop Sci. 2001, 187, 89-95. [CrossRef]

12. Streeter, J.G. Effect of nitrate on acetylene reduction activity and carbohydrate composition of Phaseolus vulgaris nodules. Physiol. Plant. 1986, 68, 294-300. [CrossRef]

13. Arnone, J.A., III; Kohls, S.J.; Baker, D.D. Nitrate Effects on Nodulation and Nitrogenase Activity of Actinorhizal Casuarin a Studied in Split-Root Systems. Soil Biol. Biochem. 1994, 26, 599-606. [CrossRef]

14. Imsande, J. Inhibition of Nodule Development in Soybean by Nitrate or Reduced Nitrogen. J. Exp. Bot. 1986, 37, 348-355. [CrossRef]

15. Dazzo, F.B.; Brill, W.J. Regulation by Fixed Nitrogen of Host-Symbiont Recognition in the Rhizobium-Clover Symbiosis. Plant Physiol. 1978, 62, 18. [CrossRef]

16. Small, J.G.C.; Leonard, O.A. Translocation of ${ }^{14} \mathrm{C}$ labeled photosynthate in nodulated legumes as influenced by nitrate nitrogen. Am. J. Bot. 1969, 56, 187-194. [CrossRef]

17. Khan, A.A.; Khan, A.A. Effects of nitrate nitrogen on growth, nodulation and distribution of ${ }^{14} \mathrm{C}$-labelled photosynthates in cowpea. Plant Soil 1981, 63, 141-147. [CrossRef]

18. Minchin, F.R.; Minguez, M.I.; Sheehy, J.E.; Witty, J.F.; Skøt, L. Relationships between nitrate and oxygen supply in symbiotic nitrogen fixation by white clover. J. Exp. Bot. 1986, 37, 1103-1113. [CrossRef]

19. Wong, P.P. Nitrate and carbohydrate effects on nodulation and nitrogen fixation (acetylene reduction) activity of lentil (Lens esculenta Moench). Plant Physiol. 1980, 66, 78-81. [CrossRef]

20. Carroll, B.J.; Hansen, A.P.; McNeil, D.L.; Gresshoff, P.M. Effect of oxygen supply on nitrogenase activity of nitrate-and dark-stressed soybean(Glycine max (L.) Merr.) plants. Funct. Plant Biol. 1987, 14, 679-687. [CrossRef]

21. Munns, D.N. Nodulation of Medicago sativa in solution culture:III. Effects of nitrate on root hairs and infection. Plant Soil 1968, 29, 33-47. [CrossRef]

22. Wahab, A.M.A.; Zahran, H.H.; Abd-Alla, M.H. Root-hair infection and nodulation of four grain legumes as affected by the form and the application time of nitrogen fertilizer. Folia Microbiol. 1996, 41, 303-308. [CrossRef] 
23. Gan, Y.; Stulen, I.; van Keulen, H.; Kuiper, P.J. Low concentrations of nitrate and ammonium stimulate nodulation and $\mathrm{N}_{2}$, fixation while inhibiting specific nodulation (nodule DW g ${ }^{-1}$, root dry weight) and specific $\mathrm{N}_{2}$, fixation $\left(\mathrm{N}_{2}\right.$, fixed $\mathrm{g}^{-1}$, root dry weight) in soybean. Plant Soil 2004, 258, 281-292. [CrossRef]

24. Harper, C.J.E. Effect of Localized Nitrate Application on Isoflavonoid Concentration and Nodulation in Split-Root Systems of Wild-Type and Nodulation-Mutant Soybean Plants. Plant Physiol. 1991, 95, 1106-1112. [CrossRef]

25. Xia, X.; Ma, C.; Dong, S.; Xu, Y.; Gong, Z. Effects of nitrogen concentrations on nodulation and nitrogenase activity in dual root systems of soybean plants. Soil Sci. Plant Nutr. 2017, 63, 470-482. [CrossRef]

26. Fujikake, H.; Yamazaki, A.; Ohtake, N. Quick and reversible inhibition of soybean root nodule growth by nitrate involves a decrease in sucrose supply to nodules. J. Exp. Bot. 2003, 54, 1379-1388. [CrossRef]

27. Kosslak, R.M.; Bohlool, B.B. Suppression of Nodule Development of One Side of a Split-Root System of Soybeans Caused by Prior Inoculation of the Other Side. Plant Physiol. 1984, 75, 125-130. [CrossRef]

28. van Brussel, A.A.; Tak, T.; Boot, K.J.; Kijne, J.W. Autoregulation of Root Nodule Formation:Signals of Both Symbiotic Partners Studied in a Split-Root System of Vicia sativa subsp.nigra. Mol. Plant Microbe Interact. 2002, 15, 41-349. [CrossRef]

29. Oghoghorie, C.G.; Pate, J.S. Exploration of the nitrogen transport system of a nodulated legume using ${ }^{15} \mathrm{~N}$. Planta 1972, 104, 35-49. [CrossRef]

30. Silva, C.F.; Paredes, D.S.; Guimarães, A.P.; Araújo, E.S.; Urquiaga, S.; Alves, B.J.R.; Boddey, R.M. Comparação entre duas técnica de marcação com ${ }^{15} \mathrm{~N}$ para avaliação do $\mathrm{N}$ residual subterrâneo da soja. In Proceedings of the Poster Presented at the Congress Fertbio, Guarapari, Brazil, 13-17 September 2010.

31. Reynolds, P.H.S.; Boland, M.J. Induction of ammonium assiniilation:leguminous roots compared with nodules using a split root system. Physiol. Plant. 1990, 79, 359-367. [CrossRef]

32. Lyu, X.; Xia, X.; Wang, C.; Ma, C.; Dong, S.; Gong, Z. Effects of changes in applied nitrogen concentrations on nodulation, nitrogen fixation and nitrogen accumulation during the soybean growth period. Soil Sci. Plant Nutr. 2019, 1-11. [CrossRef]

33. Guan, D.W.; Li, L.; Jiang, X.; Ma, M.; Cao, F.; Zhou, B.; Li, J. Influence of long-term fertilization on the community structure and diversity of soybean rhizobia in black soil. Biodivers. Sci. 2015, 23, 68-78. [CrossRef]

34. Fehr, W.R.; Caviness, C.E.; Burmood, D.T.; Pennington, J.S. Stage development description for soybean Glycine max (L.)Memll. Crop Sci. 1977, 11, 929-931. [CrossRef]

35. Crafts-Brandner, S.J.; Harper, J.E. Nitrate Reduction by Roots of Soybean (Glycine max [L.] Merr.) Seedlings. Plant Physiol. 1982, 69, 1298-1303. [CrossRef]

36. Sprent, J.I.; Thomas, R.J. Nitrogen nutrition of seedling grain legumes: some taxonomic, morphological and physiological constraints. Plant Cell Environ. 1984, 7, 637-645. [CrossRef]

37. Andrews, M. Nitrate and reduced-N concentrations in the xylem sap of Stellaria media, Xanthium strumarium and six legume species. Plant Cell Environ. 1986, 9, 605-608. [CrossRef]

38. Kiyomiya, S.; Nakanishi, H.; Uchida, H.; Tsuji, A.; Nishiyama, S.; Futatsubashi, M.; Tsukada, H.; Ishioka, N.S.; Watanabe, S.; Ito, T.; et al. Real Time Visualization of ${ }^{13} \mathrm{~N}$-Translocation in Rice under Different Environmental Conditions Using Positron Emitting Tracer Imaging System. Plant Physiol. 2001, 125, 1743-1753. [CrossRef]

39. Osa, A.; Sekine, T.; Uchida, H.; Tsuji, A.; Matsuhashi, S.; Ito, T.; Kume, T. Analysis of Nitrate Absorption and Transport in Non-nodulated and Nodulated Soybean Plants with $\mathrm{NO}_{3}{ }^{-}$and $\mathrm{NH}_{4}{ }^{+}$. Radioisotopes 1999, 48, 450-458.

40. Wery, J.; Turc, O.; Salsac, L. Relationship between growth, nitrogen fixation and assimilation in a legume (Medicago sativa L). Plant Soil 1986, 96, 17-29. [CrossRef]

41. Chaillou, S.; Rideout, J.W.; Raper, C.D., Jr.; Morot-Gaudry, J.F. Responses of soybean to ammonium and nitrate supplied in combination to the whole root system or separately in a split-root system. Physiol. Plant. 1994, 90, 260-270. [CrossRef]

42. Saravitz, C.H.; Chaillou, S.; Musset, J.; Raper, C.D., Jr.; Morot-Gaudry, J.F. Influence of nitrate on uptake of ammonium by nitrogen-depleted soybean: is the effect located in roots or shoots. J. Exp. Bot. 1994, 45, 1575-1584. [CrossRef]

43. Abdellaoui, A.; Talouizte, A. Effect of Previous Nitrogen Starvatio on $\mathrm{NO}_{3}{ }^{-}$and $\mathrm{NH}_{4}{ }^{+}$Uptake and Assimilation Associated with the Endogenous Soluble Carbohydrate Utilization in Moroccan Wheat Seedlings. J. Plant Nutr. 2007, 24, 1995-2007. [CrossRef] 
44. Schobert, C.; Komor, E. Transport of Nitrate and Ammonium into the Phloem and the Xylem of Ricinus communis seedlings. J. Plant Physiol. 1992, 140, 306-309. [CrossRef]

45. Daniels, W.L. The Nature and Properties of Soils, 15th ed.; Soil Science Society of America: Madison, WI, USA, 2016; p. 1428. [CrossRef]

46. Gianquinto, G.; Muñoz, P.; Pardossi. Soil Fertility and Plant. Good Agricultural Practices Principles for Greenhouse Vegetable Production in the Mediterranean Region. 2013, p. 205. Available online: https://www.researchgate.net/publication/256334829_Good_Agricultural_Practices_for_Greenhouse_ Vegetable_Crops_-Principles_for_Mediterranean_Climate_Areas_FAO_Ministry_of_Agriculture_Good_ Agricultural_Practices_for_greenhouse_vegetable_crops (accessed on 13 March 2020).

47. Kumar, V.; Rawat, A.K.; Rao, D.L.N. Slow and fast-growing soybean rhizobial population, their symbiotic efficiency and soil nitrogen behavior under different cropping systems in Vertisols of Madhya Pradesh. Legume Res. Int. J. 2018, 41, 617-623. [CrossRef]

48. Ito, O.; Kumazawa, K. Nitrogen assimilation in sunflower leaves and upward and downward transport of nitrogen. Soil Sci. Plant Nutr. 1976, 22, 181-189. [CrossRef]

(C) 2020 by the authors. Licensee MDPI, Basel, Switzerland. This article is an open access article distributed under the terms and conditions of the Creative Commons Attribution (CC BY) license (http://creativecommons.org/licenses/by/4.0/). 